\title{
Coccolithophore fluxes in the open tropical North Atlantic: influence of thermocline depth, Amazon water, and Saharan dust
}

\author{
Catarina V. Guerreiro ${ }^{1,6}$, Karl-Heinz Baumann ${ }^{1,2}$, Geert-Jan A. Brummer ${ }^{3,4}$, Gerhard Fischer $^{1,2}$, Laura F. Korte ${ }^{3}$, \\ Ute Merkel $^{1,2}$, Carolina Sá ${ }^{5,6}$, Henko de Stigter $^{3}$, and Jan-Berend W. Stuut ${ }^{2,3}$ \\ ${ }^{1}$ University of Bremen, Geosciences Department, Klagenfurter Str., 28359 Bremen, Germany \\ ${ }^{2}$ MARUM - Center for Marine Environmental Sciences, University of Bremen, Leobener Str. 8, 28359 Bremen, Germany \\ ${ }^{3}$ NIOZ Royal Netherlands Institute for Sea Research, Department of Ocean Systems, Den Burg 1790 AB, and Utrecht \\ University, the Netherlands \\ ${ }^{4}$ VU University, Earth and Climate Cluster, Department of Earth Sciences, Faculty of Earth and Life Sciences, \\ De Boelelaan 10851081 HV Amsterdam, the Netherlands \\ ${ }^{5}$ MARE Marine and Environmental Science Centre, Faculdade de Ciências da Universidade de Lisboa, Campo Grande, \\ 1749-016 Lisbon, Portugal \\ ${ }^{6}$ CIMA, Centre for Marine and Environmental Research, Universidade do Algarve, 8005-139 Faro, Portugal
}

Correspondence to: Catarina V. Guerreiro (catarina.guerreiro@uni-bremen.de)

Received: 29 May 2017 - Discussion started: 14 June 2017

Revised: 7 September 2017 - Accepted: 8 September 2017 - Published: 17 October 2017

\begin{abstract}
Coccolithophores are calcifying phytoplankton and major contributors to both the organic and inorganic oceanic carbon pumps. Their export fluxes, species composition, and seasonal patterns were determined in two sediment trap moorings (M4 at $12^{\circ} \mathrm{N}, 49^{\circ} \mathrm{W}$ and $\mathrm{M} 2$ at $14^{\circ} \mathrm{N}$, $37^{\circ} \mathrm{W}$ ) collecting settling particles synchronously from October 2012 to November 2013 at 1200 m of water depth in the open equatorial North Atlantic.

The two trap locations showed a similar seasonal pattern in total coccolith export fluxes and a predominantly tropical coccolithophore settling assemblage. Species fluxes were dominated throughout the year by lower photic zone (LPZ) taxa (Florisphaera profunda, Gladiolithus flabellatus) but also included upper photic zone (UPZ) taxa (Umbellosphaera spp., Rhabdosphaera spp., Umbilicosphaera spp., Helicosphaera spp.). The LPZ flora was most abundant during fall 2012, whereas the UPZ flora was more important during summer. In spite of these similarities, the western part of the study area produced persistently higher fluxes, averaging $241 \times 10^{7} \pm 76 \times 10^{7}$ coccoliths $\mathrm{m}^{-2} \mathrm{~d}^{-1}$ at station M4 compared to only $66 \times 10^{7} \pm 31 \times 10^{7}$ coccoliths $\mathrm{m}^{-2} \mathrm{~d}^{-1}$ at station M2. Higher fluxes at M4 were mainly produced by the LPZ species, favoured by the westward deepening of the thermocline and nutricline. Still, most UPZ species also
\end{abstract}

contributed to higher fluxes, reflecting enhanced productivity in the western equatorial North Atlantic. Such was the case of two marked flux peaks of the more opportunistic species Gephyrocapsa muellerae and Emiliania huxleyi in January and April 2013 at M4, indicating a fast response to the nutrient enrichment of the UPZ, probably by wind-forced mixing. Later, increased fluxes of G. oceanica and E. huxleyi in October-November 2013 coincided with the occurrence of Amazon-River-affected surface waters. Since the spring and fall events of 2013 were also accompanied by two dust flux peaks, we propose a scenario in which atmospheric dust also provided fertilizing nutrients to this area. Enhanced surface buoyancy associated with the river plume indicates that the Amazon acted not only as a nutrient source, but also as a surface density retainer for nutrients supplied from the atmosphere. Nevertheless, lower total coccolith fluxes during these events compared to the maxima recorded in November 2012 and July 2013 indicate that transient productivity by opportunistic species was less important than "background" tropical productivity in the equatorial North Atlantic. This study illustrates how two apparently similar sites in the tropical open ocean actually differ greatly in ecological and oceanographic terms. The results presented here provide valuable insights into the processes governing the ecological 
dynamics and the downward export of coccolithophores in the tropical North Atlantic.

\section{Introduction}

The centres of subtropical gyres and tropical open-ocean regions are marked by nearly permanently stratified waters, which result in nutrient depletion at the surface and low primary production, particularly at the surface during most of the year (see Mann and Lazier, 2006). With the exception of equatorial upwelling areas where the renewal of nutrients in the mixed layer results from the upward advection of nutrient-rich deeper water, algal blooms in subtropical gyres and tropical oceans are highly dependent on the seasonal dynamics of the mixed layer depth, the latter changing as a geostrophic response to the wind field and the curl of the wind stress (e.g. Longhurst et al., 1995). Basin-scale thermocline tilting, mesoscale eddies, and vertical mixing due to wind forcing and winter cooling are recognized as the main mechanisms responsible for bringing nutrients to the upper photic layer and promoting algal blooms in tropical and subtropical areas (e.g. Longhurst, 1993; Dufois et al., 2016). In addition, millions of tons of Saharan dust blown over and into the Atlantic Ocean every year are also thought to act as major nutrient suppliers to the nutrient-depleted equatorial North Atlantic (see Goudie and Middleton, 2001 and refs. therein; Okin et al., 2011). The fertilizing potential of Saharan dust is supported by previous studies in the Amazon Basin (Mahowald et al., 2008, 2009; Bristow et al., 2010), the Gulf of Mexico and the coast of southern Florida (Walsh et al., 2006; Lenes et al., 2012), and the North Atlantic subtropical gyre (Pabortsava et al., 2017). In addition to Saharan dust inputs, $\mathrm{N}_{2}$ fixation by marine diazotrophs (Carpenter et al., 1999) and the seasonal discharge and eastward advection of the nutrient-enriched Amazon River Plume (e.g. De Master et al., 1986) are additional nutrient sources for marine phytoplankton in the tropical Atlantic.

Despite relatively low primary production rates, tropical oceans play an important role in the global carbon cycle because of their large surface area (e.g. Wang et al., 2013; Signorini and McClain, 2012; Longhurst, 1993). How these oceanographic and atmospheric processes are linked to phytoplankton productivity on seasonal to annual timescales in the tropics, however, remains poorly understood. As longerterm phytoplankton sampling in the vast and remote open ocean is rather costly, most of the available studies are based on data from snapshots taken during research cruises or remote-sensing estimates that only cover the phytoplankton biomass at the surface of the photic layer. Time-series sediment traps collecting settling particles (organic and inorganic) from phytoplankton export productivity over longer periods of time (from weeks to years) offer a good alternative to plankton studies for assessing the seasonal variation of marine phytoplankton and the relative proportion of indi- vidual species or groups of species in the open ocean (e.g. Milliman, 1993; Baumann et al., 2005).

Coccolithophores, being at the same time photosynthetic and calcifying, are major contributors to the organic and inorganic oceanic carbon pumps (e.g. Rost and Riebesell, 2004). Due to their ability to cover their cells with tiny calcite plates (the coccoliths), coccolithophores can be studied in time series samples collected by deep-ocean sediment traps (e.g. Broerse et al., 2000; Sprengel et al., 2002; Ziveri et al., 1995; Köbrich et al., 2015), thus providing insight into the seasonal to inter-annual dynamics of open-ocean phytoplankton. Coccolithophores are amongst the most important phytoplankton groups within open-ocean, stratified oligotrophic waters (e.g. Winter et al., 1994), hence displaying features more typical of $K$-selected taxa (Margalef, 1978). These so-called " $K$ selected" taxa are typically better adapted to compete successfully for limited nutrient availability in more stable environments, such as tropical regions and subtropical gyres, within populations that are at or near equilibrium conditions for long periods of time ( $K$; see Margalef, 1978). Still, coccolithophores also include more opportunistic taxa, so-called " $r$-selected", that quickly respond to short-term changes associated with nutrient input (e.g. Guerreiro et al., 2013). The latter are characterized by living in highly variable populations (for $r$ ) and being well adapted to rapidly reproducing in unstable and nutrient-enriched conditions, such as turbulent coastal environments. Sediment trap studies using this group are based on the assumption that the settling of coccoliths in open-ocean areas is primarily related to the production occurring in the overlying photic layer (see Deuser et al., 1981; Honjo, 1982; Steinmetz, 1994; Beaufort and Heussner, 2001), allowing for the assessment of the export fluxes and seasonal trends of distinct coccolithophore species during longer periods than most plankton studies (Baumann et al., 2005).

Although a significant amount of sediment trap data on coccolithophores fluxes exists for the open ocean (e.g. Knappertsbusch and Brummer, 1995; Broerse et al., 2000) and for regions near continental margins and islands (Beaufort and Heussner, 2001; Romero et al., 2002; Köbrich et al., 2015; Sprengel et al., 2002) at subtropical and temperate latitudes in the Atlantic, there is no information available on the export and seasonal patterns of coccolithophores in the equatorial Atlantic region. Previous studies by Kinkel et al. (2000) and Winter et al. (2002) focusing on the living coccolithophore communities in the tropical Atlantic have reported Florisphaera profunda as the dominant species in the lower photic zone (LPZ) and Emiliania huxleyi as the dominant species in the upper photic zone (UPZ) close to the equatorial upwelling and in the western Caribbean Sea, whereas Umbellosphaera spp. were most abundant in the UPZ of more open-ocean oligotrophic areas. Further north, in the subtropics of offshore Bermuda, Haidar and Thierstein (2001) studied the relationship between the seasonal coccolithophore dynamics and several environmental param- 
eters, including light, dissolved nutrients, salinity, and temperature, over a period of 3 years. The results showed that living coccolithophores display pronounced seasonal and interannual variability, with the highest standing stocks from winter to spring and the lowest during summer. E. huxleyi was the dominant species at the surface during spring, whereas the LPZ species F. profunda and Gladiolithus flabellatus (referred to by these authors as Thoracosphaera flabellata) were most common below the surface during fall. During maximum stratification conditions in summer and fall, Umbellosphaera spp. increase in abundance in the top $75 \mathrm{~m}$ of water depth but in much lower cell densities than $E$. huxleyi or $F$. profunda. Several of these previous observations were confirmed by Poulton et al. (2017), who defined three floral depth groups in the subtropical gyres and equatorial waters of the Atlantic Ocean: (1) an upper euphotic zone flora characterized by high levels of surface radiance and high cell densities of Umbellosphaera spp. and holococcolithophores; (2) a lower euphotic zone flora characterized by intermediate to low surface radiance levels and high cell densities of E. huxleyi and Gephyrocapsa ericsonii; and (3) a subeuphotic zone flora characterized by high cell densities of F. profunda and Gladiolithus spp. thriving below the depth at which light is considered sufficient to support photosynthesis, probably by mechanisms of mixotrophy and/or phagotrophy. Therefore, more insight into the ecological preferences and environmental needs of coccolithophores can be expected from a clear distinction between the distribution and abundance of UPZ and LPZ taxa.

Here, we present new data on the coccolithophore export fluxes, seasonal patterns, and species composition from the open equatorial North Atlantic to investigate the environmental factors triggering phytoplankton productivity, including Saharan dust deposition and the discharge and eastward dispersion of the Amazon River water. To assess the spatiotemporal variability of these processes, we (a) compare results from two sediment trap moorings, M2 and M4, located in the central and western parts of the equatorial North Atlantic, respectively, and (b) relate coccolithophore data with environmental time series data obtained from satellite remote sensing for the sediment trap sampling period and with particle flux data collected from the same sediment traps and recently published by Korte et al. (2017).

\section{Oceanographic and meteorological settings}

Surface water circulation in the study area, involving tropical surface water (TSW) and the South Atlantic Central Water (SACW), is mostly driven by the north-easterly trade winds responsible for generating the westward-flowing North Equatorial Current (NEC) between approximately 10 and $20^{\circ} \mathrm{N}$ (Fig. 1). South of the NEC is the North Equatorial Counter Current (NECC) flowing in the eastward direction counter to the wind (Stramma and Schott, 1999).
Both currents are subjected to the latitudinal migration of the Intertropical Convergence Zone (ITCZ) between approximately $5^{\circ} \mathrm{S}$ and $12^{\circ} \mathrm{N}$ depending on the season (Basha et al., 2015). During boreal summer when the ITCZ is at its northernmost position, the SE trade winds intensify along the Equator, even penetrating into the Northern Hemisphere and intensifying the surface circulation. Between summer and late fall, the NECC flows along an equatorial band centred between 5 and $8^{\circ} \mathrm{N}$ (Longhurst, 1993; Garzoli and Katz, 1983). During the same period an important part of the northward-flowing North Brazilian Current (NBC) is retroflected off the South American north-eastern margin towards the east into the western tropical North Atlantic after crossing the Equator (approximately at $8^{\circ} \mathrm{N}$ and $50^{\circ} \mathrm{W}$; Philander, 2001), feeding into the NECC (Richardson and Walsh, 1986), and often expanding northward through the shedding of anticyclonic eddies drifting in the NW direction (Schott et al., 1998; Fig. 1). During boreal winter, the southward migration of the ITCZ causes the weakening of the trade winds along the Equator and the concomitant disappearance of the NECC in the western part of the equatorial region. This results in a generally westward-flowing circulation in the equatorial North Atlantic north of the Equator west of $25^{\circ} \mathrm{W}$ (Stramma and Schott, 1999). At the same time, the NBC ceases to retroflect but rather continues to flow north-westward along the continental slope off the coast of South America (Johns et al., 1998; Lux et al., 2001; Philander, 2001). This is the period of maximum northward transport of heat across the Equator (Philander, 2001), for which the NBC is the main pathway (Goni and Johns, 2001).

The western equatorial North Atlantic where station M4 was located is also seasonally influenced by the Amazon River, the world's largest river with respect to freshwater discharge into the open ocean (Mann and Lanzier, 2006). From August to December, when the retroflection of the NBC carries the river plume eastward in the uppermost $\sim 50 \mathrm{~m}$ of the water column, large amounts of nutrients (Boyle et al., 1977; Sholkovitz et al., 1978; De Master et al., 1986) are entrained into the NECC far into the central equatorial North Atlantic (Muller-Karger et al., 1988; Molleri et al., 2010; Ffield, 2005; Fig. 1). From August to October, the Amazon Plume was observed to reach speeds of $\sim 90 \mathrm{~cm} \mathrm{~s}^{-1}$ near $45^{\circ} \mathrm{W}$ with a gradual slowdown to $30 \mathrm{~cm} \mathrm{~s}^{-1}$ while moving eastward. Near the African continent, a part of it continued into the Guinea Current, while another part moved northward into the NEC and then westward (e.g. Muller-Karger et al., 1988; Molleri et al., 2010).

The upper water masses in the study area, including the mixed layer, consist mostly of the warm, salty, and nutrientdepleted TSW in the upper $\sim 100 \mathrm{~m}$ (temperature $-T$ : $\sim 27^{\circ} \mathrm{C}$, salinity $\left.-S: 36.7-37\right)$ and the cooler, less salty, and relatively nutrient-enriched South Atlantic Central Water (SACW) at depths down to $\sim 500 \mathrm{~m}\left(T: 6.0-18^{\circ} \mathrm{C}, S: 34.3-\right.$ 35.8). Further down to $1200 \mathrm{~m}$ of water depth the Antarctic Intermediate Water (AAIW) is characterized by a subsurface 


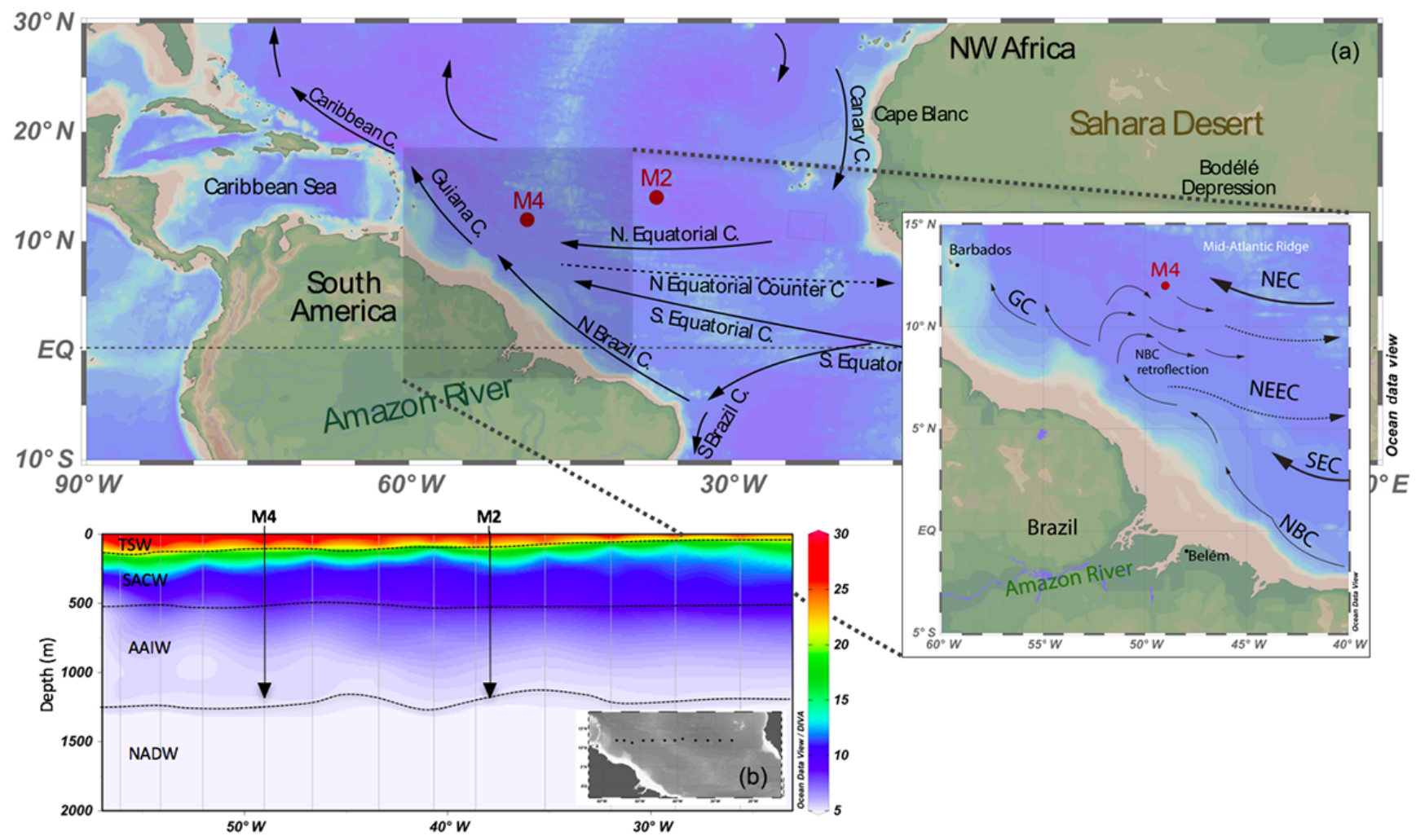

Figure 1. Location of the trap mooring sites M4 and M2 and a schematic representation of (a) the main surface currents in the equatorial Atlantic Ocean, with the inset showing the seasonal eastward retroflection of the North Brazilian Current (NBC) during boreal summer (adapted from Mann and Lazier, 2006). (b) The main water masses present in the study area (TWS - tropical surface water; SACW - South Atlantic Central Water; AAIW - Antarctic Intermediate Water; NADW - North Atlantic Deep Water) based on water depths reported by Emery and Meincke (1986), Reid (1994), and Stramma and Schott (1999) and on water temperature profiles performed along a transatlantic array $\left(12^{\circ} \mathrm{N}\right)$ from 12 January and 2 February 2015 on-board RV Pelagia (cruise PE395; Stuut et al., 2015).

oxygen maximum and a salinity minimum $\left(T: 2-6^{\circ} \mathrm{C}, S\right.$ : 33.8-34.8; Emery and Meincke, 1986; Reid, 1994; Stramma and Schott, 1999). Below the AAIW is the cold North Atlantic Deep Water (NADW) flowing southward between 1200 and 4000 m (Stramma and Schott, 1999; see Fig. 1b)

\section{Material and methods}

\subsection{Sediment trap sampling}

Two sediment traps at sites $\mathrm{M} 2\left(14^{\circ} \mathrm{N}, 37^{\circ} \mathrm{W}\right)$ and $\mathrm{M} 4$ $\left(12^{\circ} \mathrm{N}, 49^{\circ} \mathrm{W}\right)$ collected sinking particles in synchronous intervals of 16 days from 19 October 2012 to 7 November 2013 in the central and western equatorial North Atlantic, respectively (Fig. 1, Table 1). Details of the mooring equipment, the deployment and recovery of the sediment traps, and the treatment of the recovered sample bottles are described in Stuut et al. (2013).

\subsection{Laboratory and microscope analysis}

Sediment trap samples from stations M4 and M2 were initially wet-sieved over a $1 \mathrm{~mm}$ mesh, wet-split into five aliquot subsamples using a rotary splitter (WSD-10; McLane Laboratories), washed to remove the $\mathrm{HgCl}_{2}$ and salts, and centrifuged. Average weight differences between replicate aliquots were within $2.4 \%(\mathrm{SD}=2.2)$, with $87 \%$ of all samples differing $<5 \%$ between splits (detailed procedure in Korte et al., 2017). Micropalaeontological analysis was undertaken from one $1 / 5$ split of each original sample after being oxidized in a low-temperature asher for approximately $4 \mathrm{~h}$ to remove the organic matter and obtain a sample strictly composed of mineral particles (Fallet et al., 2009). The coccolith export fluxes and species composition were assessed following the methods described in Andruleit (1996). Depending on the particle content of the samples, a split of usually $1 / 2000$ of the original sample was filtered onto polycarbonate membrane filters $(47 \mathrm{~mm}$ diameter, $0.45 \mu \mathrm{m}$ pore size). The only exception was the material-loaded sample M4-24 for which a split of 1/16000 was necessary. Once dried, a segment of each filter was cut and mounted on 
Table 1. Background information regarding the DUSTTRAFFIC sediment trap moorings (M4 and M2) used in this study.

\begin{tabular}{lrr}
\hline Mooring station & M4 & M2 \\
\hline Position & $12^{\circ} \mathrm{N} 49^{\circ} \mathrm{W}$ & $14^{\circ} \mathrm{N} 37^{\circ} \mathrm{W}$ \\
Trap depth (m) & 1130 & 1235 \\
Bottom depth (m) & 4670 & 4790 \\
Sampling period & 19 Oct 2012-7 Nov 2013 & 19 Oct 2012-7 Nov 2013 \\
Number of studied samples & 23 & 23 \\
Sampling resolution (days) & 16 & 16 \\
\hline
\end{tabular}

a scanning electron microscope (SEM) stub. A minimum of 500 coccoliths was then counted from an arbitrarily chosen transect and each coccolith was identified to the lowest taxonomic level possible at $3000 \times$ magnification using a Zeiss DSM 940A SEM at $10 \mathrm{kV}$ of accelerating voltage.

The taxonomic identification of coccolithophore species followed Jordan et al. (2004) and Young et al. (2011). Coccolith species counts were converted into coccolith export fluxes (i.e. coccoliths $\mathrm{m}^{-2} \mathrm{~d}^{-1}$ ) by extrapolating to the entire effective filter area and to the original sample and dividing by the sample interval and the trap aperture area. Finally, the Shannon-Weaver diversity index $H^{\prime}$ (e.g. Tuomisto, 2013) was determined to assess the coccolithophore species diversity at each location.

Shallowing or deepening of the nutricline was inferred from the ratio between upper photic zone (UPZ) species and lower photic zone (LPZ) species, with larger ratios (i.e. higher abundance of UPZ taxa) indicating shallower depths of the nutricline. The ratio was calculated as the sum of the fluxes of Gephyrocapsa muellerae, G. oceanica, and Emiliania huxleyi divided by the sum of the fluxes of Florisphaera profunda and Gladiolithus flabellatus (e.g. Molfino and McIntyre, 1990; Beaufort et al., 1997; Stoll et al., 2007). In spite of also being considered an LPZ species, Reticulofenestra sessilis was not included in the equation due to its much lower export fluxes and different seasonality compared to the latter two species.

\subsection{Oceanographic and meteorological data}

Time series of hydrological (sea surface temperature - SST, salinity - SSS, and Chl $a$ concentrations) and meteorological parameters obtained from satellite data (i.e. daily precipitation rates, photosynthetically available radiance (PAR), wind speed) were used as a complementary framework for interpreting the influence of environmental variability on the coccolithophore export fluxes (Table 2). The aerosol optical depth (AOD) was used as a measure of aerosols distributed within a column of air from the top of the atmosphere to the surface of the Earth. Based on Lelli et al. (2014), spatiotemporal variations in AOD during the sampling period were interpreted as an indicator of the atmospheric aerosols originating from the African deserts. The percentage of cloud cover was estimated from MODIS data as the percentage of pixels in the image flagged (L2-flags) with "probable cloud or ice contamination". For each trap location, satellite data were retrieved considering a $2^{\circ} \times 2^{\circ}$ latitude-longitude area centred around the trap location and averaged for each 16day interval of the sediment trap sampling period. The $2^{\circ} \times 2^{\circ}$ box, corresponding to $\sim 119 \times 119 \mathrm{Nmi}\left(1^{\circ}=\sim 59 \mathrm{Nmi}\right)$, was assumed to be representative of the catchment area of a trap deployed at $1200 \mathrm{~m}$ of depth, taking into account the sinking speed for marine phytoplankton and algal aggregates (e.g. Waniek et al., 2000) and based on temperature-pressure measurements; this indicates that M2 and M4 were equally and effectively vertical during the deployment period (Korte et al., 2017). Data were downloaded from various sources as listed in the Supplement and processed for the study period 2012-2013, as shown in Fig. 2.

\subsection{Statistical multivariate analysis}

The relationship between the coccolithophore taxa and the environmental conditions during the monitored period was investigated on the basis of a statistical multivariate analysis ( $r$-mode factor analysis; Statistica 13) performed upon a data matrix of 46 samples (i.e. cases) and 17 variables (columns). The factor analysis considered only the percentages of the 10 most common species or taxonomic groups (i.e. $>2 \%$ of the annual mean assemblage in at least one of the stations) and the hydrological and meteorological parameters obtained from satellite data (SST, SSS, Chl $a$, PAR, precipitation rate, AOD, and wind speed). Results from the original data matrices were optimized through a varimax raw rotation and the obtained factor scores were plotted against time to assess the temporal variability of the factors at both mooring locations.

\section{Results}

\subsection{Oceanographic and meteorological conditions during the sampling period}

The seasonal development of sea surface conditions did not differ drastically between the two mooring stations during the monitored period, despite considerable differences in the range of values of salinity and Chl $a$ concentrations (Fig. 2). SST tended to be lower from late winter to early summer 

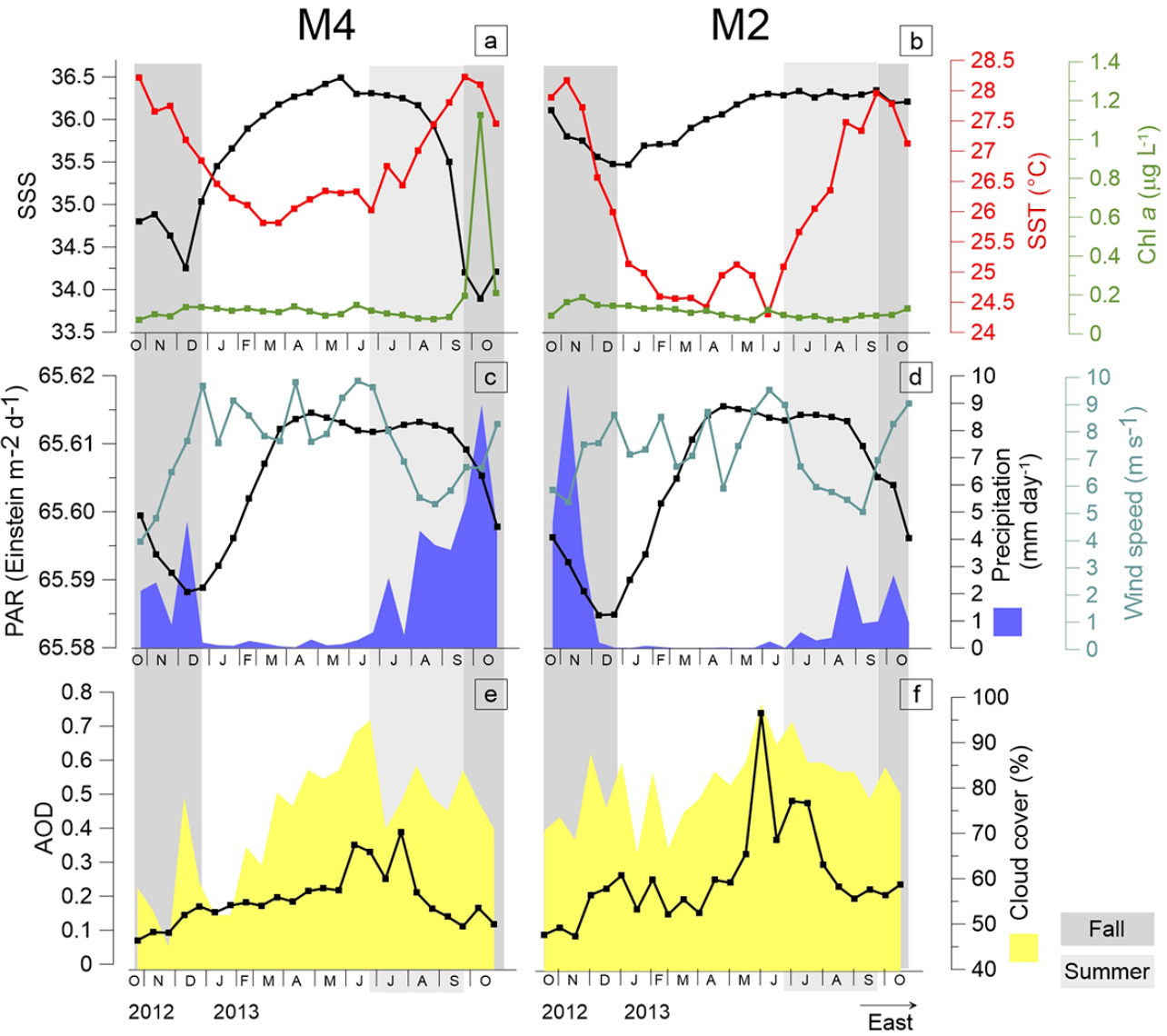

Figure 2. Time series of relevant atmospheric and oceanographic parameters during the monitored time interval determined from remote sensing; (a, b) sea surface temperature (SST), sea surface salinity (SSS) and Chl $a$ concentrations, (c, d) photosynthetic available radiance (PAR), precipitation rate and wind speed, and $(\mathbf{e}, \mathbf{f})$ aerosol optical depth (AOD) and cloud cover percentage (for data sources and processing, see the Supplement and Sect. 3.3). Dark and light grey bands refer to fall and summer, respectively.

and higher during late summer and fall in both areas, although it was generally higher at station M4 $\left(26.2-29.2^{\circ} \mathrm{C}\right)$ than at M2 $\left(24.3-28.2^{\circ} \mathrm{C}\right)$. SST minima were recorded in late March and April 2013 at station M4 and in late March and late May of the same year at station M2. Differences were, however, encountered in terms of the range and seasonal patterns of SSS. Whereas station M2 revealed little variability in surface salinity (35.5-36.3), station M4 experienced a sharp and quite distinct decrease during the fall months, particularly in October-November 2013 (33.9-36.5). Surface Chl $a$ concentrations were generally low during most of the year at both stations $\left(\sim 0.1 \mu \mathrm{g} \mathrm{L}^{-1}\right)$ but distinctively increased in October-November 2013 at station M4 (up to $1.13 \mu \mathrm{gL}^{-1}$ ) (Fig. 2a, b).

Atmospheric conditions were similar at both locations. Despite the narrow range of PAR values observed at both stations, a clear seasonality is evidenced from slightly higher PAR during spring and summer (up to 65.615 Einstein $\mathrm{m}^{-2} \mathrm{~d}^{-1}$ in April 2013) towards slightly lower PAR during fall and winter (down to 65.588 Einstein $\mathrm{m}^{-2} \mathrm{~d}^{-1}$ in December 2012) at both stations (Fig. 2c and d). Precipitation rates were higher during summer and fall, up to $10 \mathrm{mmd}^{-1}$ in early November 2012 at $\mathrm{M} 2$ and up to $9 \mathrm{mmd}^{-1}$ in September-October 2013 at M4. Both stations received little to no precipitation during the winter and spring months (Fig. 2c and d). Winds were stronger albeit variable during winter and spring and then dropped during the summer months to gradually increase again during the following fall. Slightly stronger winds prevailed during winter and spring at M4 (up to $10 \mathrm{~ms}^{-1}$ in December 2013, April, and June 2013) and during spring, summer, and fall at M2 (up to $9.5 \mathrm{~m} \mathrm{~s}^{-1}$ in May-June and October-November 2013; Fig. 2c and d). AOD had a similar month-to-month variation at both locations, generally increasing during the spring-summer transition but reaching higher values at station M2, particularly in May-June 2013 (up to 0.85), compared to M4 (only 0.35; Fig. 2e and f). Cloud cover percentage was fairly variable during the sampling period, generally higher at station M2 with a tendency to increase during spring and summer. Clouds and AOD appear weakly covariant (ascending) during winter and spring, whereas during summer and fall the discrepancy between the two parameters increases, point- 

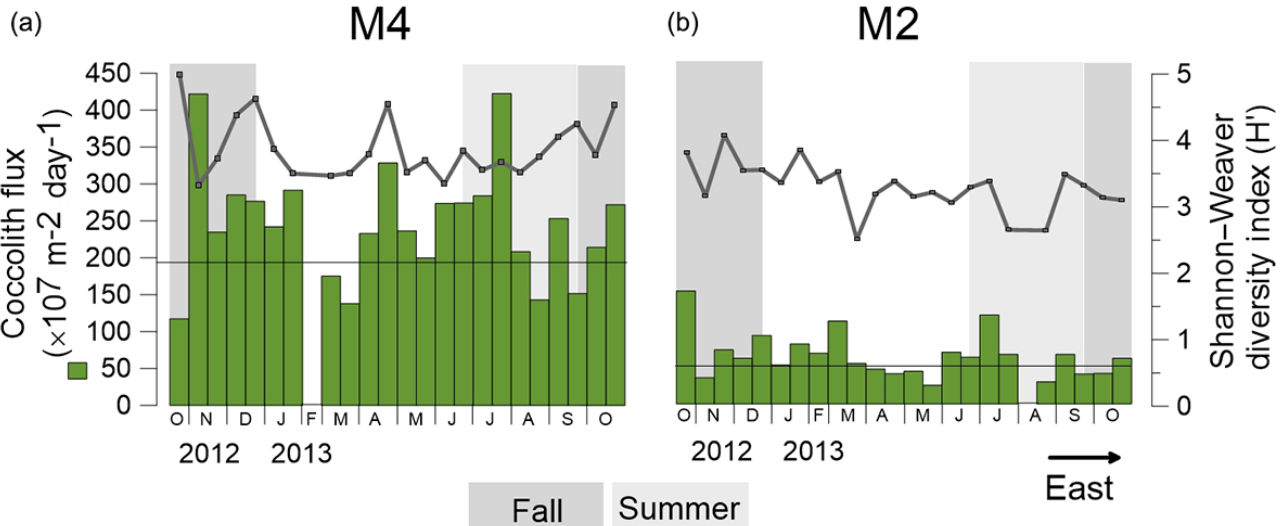

Figure 3. Temporal variation in total coccolith export fluxes (coccolith $\mathrm{m}^{-2} \mathrm{~d}^{-1}$; green bars), Shannon-Weaver diversity index $\left(H^{\prime}\right.$; solid grey line), and annual mean coccolith flux (horizontal black line) at trap stations M4 (a) and M2 (b).

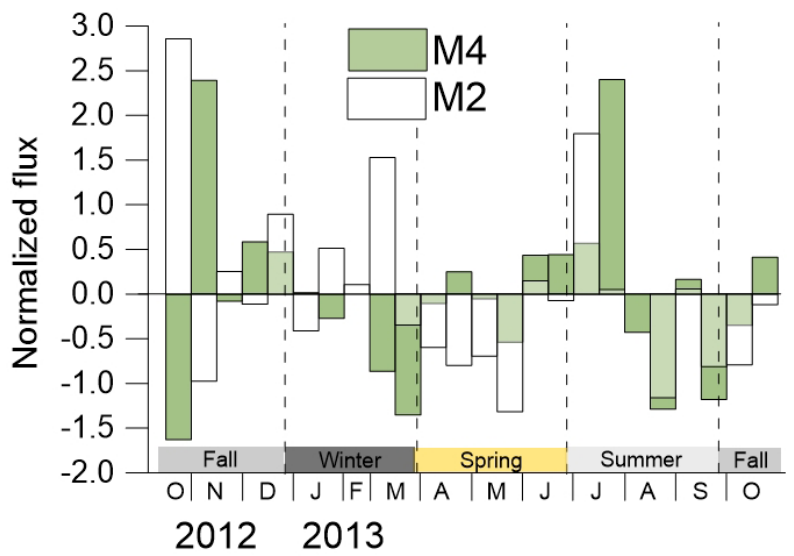

Figure 4. Deviation from the annual mean coccolith flux determined for trap stations M4 (green) and M2 (transparent white).

ing to a higher error in dust flux estimates from AOD during summer and fall (Fig. 2e and f).

\subsection{Total coccolith fluxes at stations M4 and M2}

Station M4 received much higher fluxes than M2 during most of the year, reaching an annual mean of $241 \times 10^{7} \pm 76 \times$ $10^{7}$ coccoliths $\mathrm{m}^{-2} \mathrm{~d}^{-1}$ compared to only $66 \times 10^{7} \pm 31 \times$ $10^{7}$ coccoliths $\mathrm{m}^{-2} \mathrm{~d}^{-1}$ at station M2 (Fig. 3, Table 3). In spite of this conspicuous contrast, the two stations revealed an overall similar temporal variation in coccolith fluxes, with maxima during the fall of 2012 (in early November at M4 and late October in M2) and during the summer of 2013 (in late July at M4 and early July at M2) and minima during the fall of 2012 (late October at M4 and early November at M2), spring 2013 (late March at M4 and late May at M2), and the summer-fall transition in 2013 (at both stations). Only from January to March 2013 did stations M4 and M2 diverge with fluxes below and above the corresponding annual means, respectively (Figs. 3 and 4).

\subsection{Coccolithophore species fluxes and relative abundances}

The number of species or groups of species was similar at stations M4 and M2 (47 and 43 taxa, respectively) although slightly higher at the westernmost site as also indicated by the higher Shannon-Weaver diversity index $\left(H^{\prime} ;\right.$ Fig. 3). The $H^{\prime}$ value was highest during the fall of 2012 and later in April and October-November 2013 at M4. It was highest during late November 2012 and lowest in March-April and JulyAugust of 2013 at M2 (Fig. 3). In spite of this species diversity, only 10 taxa occurred in abundances of $\geq 2 \%$ in at least one of the stations and were selected for our further analysis (see Figs. 5 and 6). Mean, minimum, and maximum coccolith fluxes and percentages for each taxon or group of taxa are given in Table 3. The dominant taxa by far were the LPZ species Florisphaera profunda and Gladiolithus flabellatus, with fluxes together comprising 74 and $69 \%$ of the annual mean flux at M4 and M2, respectively. The remaining taxa, including Emiliania huxleyi, Umbellosphaera spp., Rhabdosphaera spp., Helicosphaera spp., Umbilicosphaera spp., Reticulofenestra sessilis, Gephyrocapsa muellerae, and G. oceanica, exhibited mean percentages of 2-7\% (Table 3, Fig. 5).

Most of the taxa produced much higher coccolith fluxes at the western station M4. Such was particularly the case of F. profunda, G. flabellatus, and E. huxleyi, with maximum fluxes nearly 3-5 times higher at M4 than at M2. It was also the case of the UPZ species G. muellerae and G. ocean$i c a$, which recorded flux maxima up to 72 and 26 times higher at M4, respectively. Species within Umbellosphaera, Rhabdosphaera, Umbilicosphaera, Helicosphaera, and $R$. sessilis had more similar ranges of abundance at the two sites. In terms of relative abundance, however, all the species 

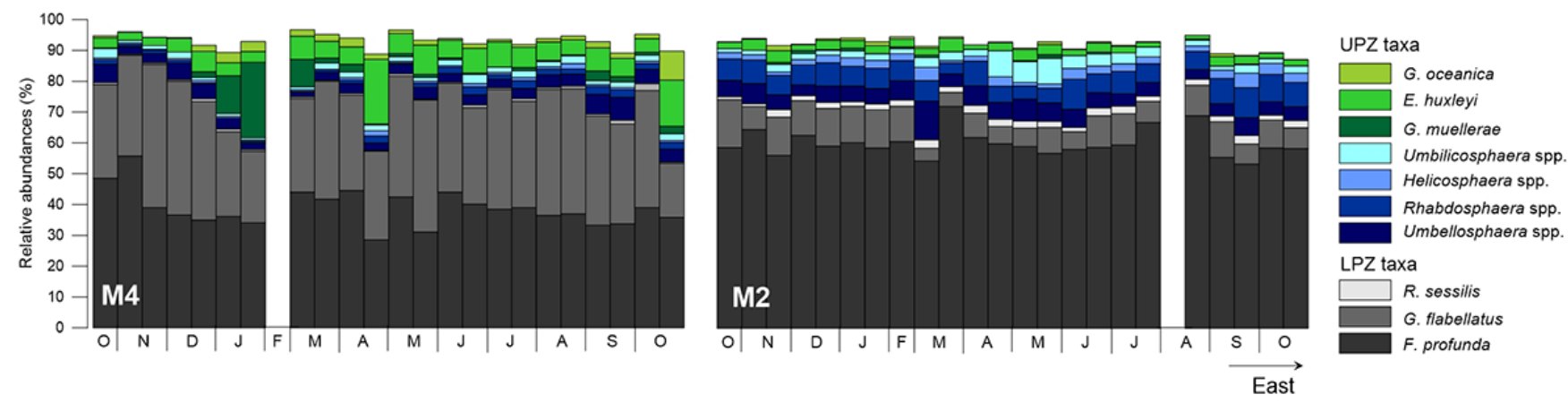

Figure 5. Percentage of the most abundant coccolithophore taxa (>2\%) at stations M4 and M2.

recorded higher percentages at station M2 compared to M4, with the exception of G. flabellatus, E. huxleyi, and species within Gephyrocapsa spp.

\subsubsection{Site M4}

Coccoliths produced by $F$. profunda (29-56\%) were high in November 2012 and late July 2013, with lower fluxes in October 2012, late March, late August, and late September 2013. In terms of relative abundances, F. profunda was most common in early November 2012 and least common in late April 2013 (Fig. 6a). A similar seasonal pattern was shown by G. flabellatus (18-47\%) but with a less abrupt decrease in the transition to spring compared to F. profunda. Lower fluxes of G. flabellatus occurred in October 2012, March, and October-November 2013, whereas its relative abundances generally followed the same seasonal pattern of the fluxes (Fig. 6b). Seasonality in Umbellosphaera spp. (2-8\%) and $R$. sessilis $(0.2-2 \%)$ was somewhat similar to that of G. flabellatus. Maximum fluxes of Umbellosphaera spp. occurred in December 2012 and September 2013, and lower fluxes occurred from late winter to early spring, with higher percentages in October and December 2012 and later in September 2013 (Fig. 6d). Flux maxima of R. sessilis occurred in late December 2012 and late July and early October 2013, and flux minima occurred in October 2012, late March, late April, and late May 2012 (Fig. 6h).

Rhabdosphaera spp. (0-3\%) and Umbilicosphaera spp. (1-3\%) revealed similar seasonal patterns, with the highest fluxes recorded during spring and summer and maxima in late July 2013 and later in April and June 2013 (Fig. 6e and g). In the case of Umbilicosphaera spp., flux increases were also noticed in early December 2012 and November 2013. The lowest fluxes of both taxa were recorded from January to March 2013. The seasonal pattern of their relative abundance generally followed that of the coccolith export fluxes. In spite of some similarity with the latter taxa, Helicosphaera spp. (0.1-2\%) was clearly more abundant in late April and late July, with the lowest fluxes from late summer to late winter (Fig. 6f), whereas E. huxleyi
(0.1-2\%) showed two distinct and very sharp peaks in late April 2013 and in October-November 2013 (Fig. 6c).

Gephyrocapsa muellerae (0-25\%) occurred in persistently low fluxes and percentages throughout the year but remarkably increased in January 2013 (Fig. 6i). Seasonality in G. oceanica $(0.1-9 \%)$ was somewhat in between G. muellerae and E. huxleyi, but it was slightly more abundant from December 2012 until April 2013 and strikingly increased in October-November 2013 (Fig. 6j).

\subsubsection{Site M2}

In comparison to the western site where different species revealed distinct seasonal variations, at the more central site M2 most of the taxa revealed a very similar seasonality, with the highest fluxes in late October 2012 and early July 2013 and lower fluxes in early November 2012, late May, and August 2013 (Fig. 6) The exceptions were G. flabellatus (Fig. 6b), which was the only one of the most abundant species without a flux increase in early March 2013, and $\mathrm{He}$ licosphaera spp. (Fig. 6f), which were clearly more abundant from late winter to early summer 2013.

F. profunda (53-72\%) stood out for being much more common at site M2 compared to M4 (Fig. 6a), and species within Umbellosphaera spp. (4-10\%), H. carteri (1-9\%), Rhabdosphaera spp. (1-5\%), Umbilicosphaera spp. (1$5 \%$ ), and $R$. sessilis (1-4\%) were also generally more common in this area than at M4 (Fig. 6d-h). By contrast, G. flabellatus (4-16\%), E. huxleyi (3-13\%), G. oceanica (0-2\%), and $G$. muellerae (0-1\%) revealed much lower fluxes and percentages as well as comparatively low month-to-month variation in fluxes compared to M4 (Fig. 6b, c, i, and j).

\subsection{Coccolithophore variability from multivariate factor analysis}

Four factors were extracted from the multivariate factor analysis, together explaining $63 \%$ of the total variability within the data (Fig. 7, Table 3). Factor 1 (F1, explaining $30 \%$ of the total variance) is represented by F. profunda, R. sessilis, Umbellosphaera spp., Helicosphaera spp., and Rhabdosphaera 

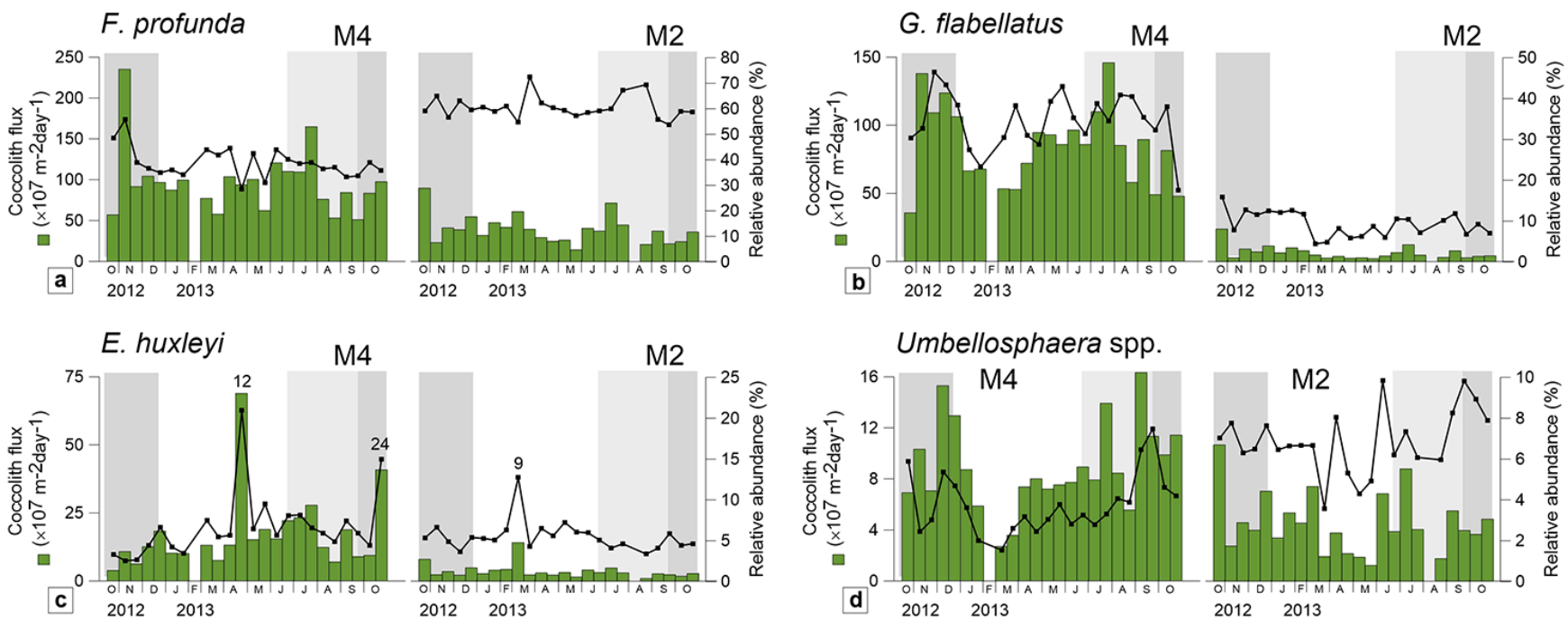

Umbellosphaera spp.

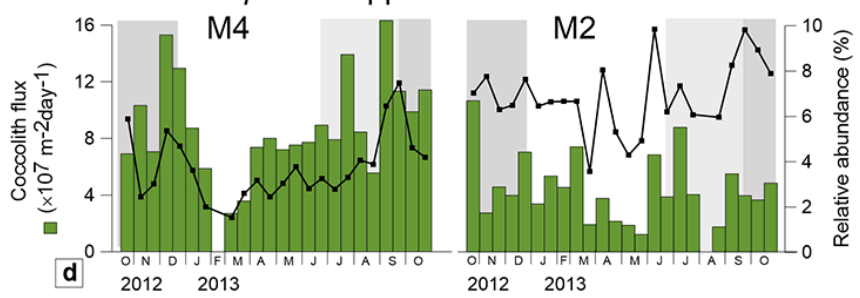

Rhabdosphaera spp.

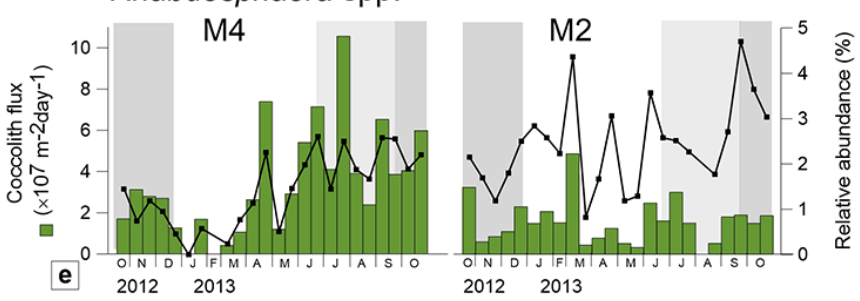

Helicosphaera spp.

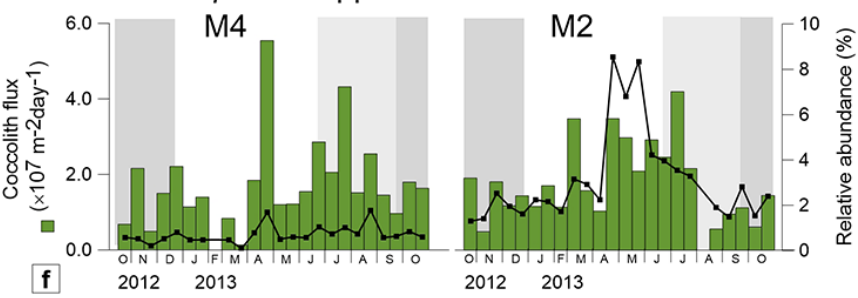

Umbilicosphaera spp.
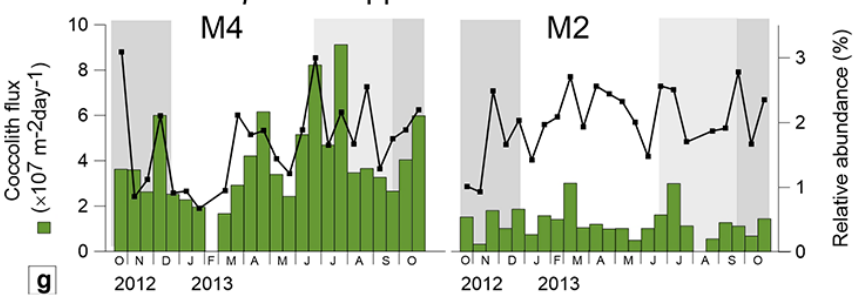

R. sessilis
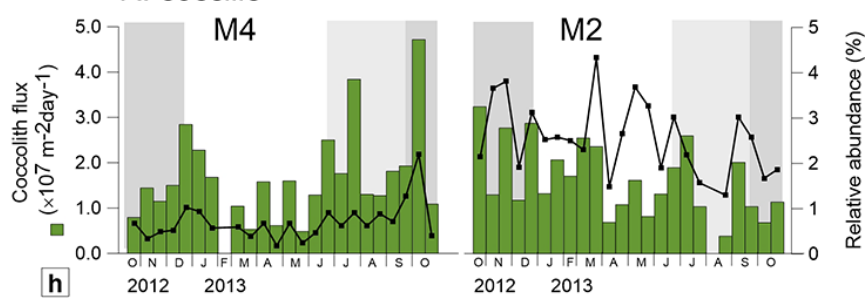

G. muellerae
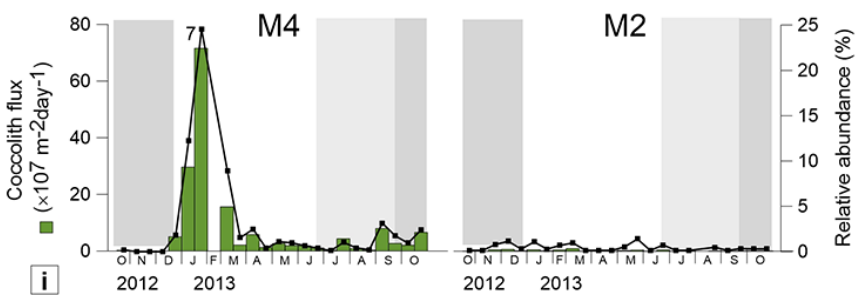

G. oceanica

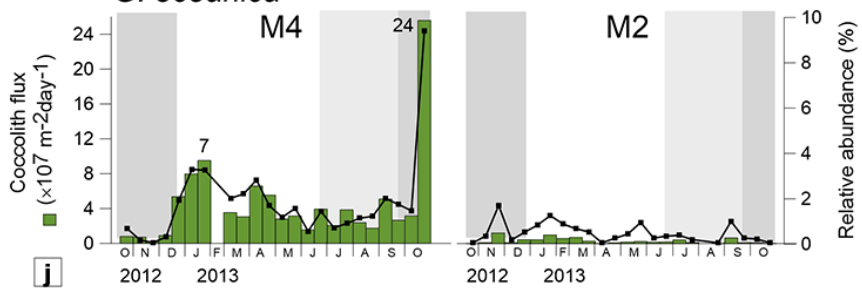

Figure 6. Coccolith export fluxes and relative abundance of the most important species at stations M4 and M2: (a) F. profunda, (b) G. flabellatus, (c) E. huxleyi, (d) Umbellosphaera spp., (e) Rhabdosphaera spp., (f) Helicosphaera spp., (g) Umbilicosphaera spp., (h) R. sessilis, (i) G. muellerae, and (j) G. oceanica. Dark and light grey bars indicate boreal fall and summer, respectively. Numbers 7, 12, and 24 indicate the sample reference for the time intervals during which G. muellerae, E. huxleyi, and G. oceanica produced "pulse-like" maxima at station M4 (i.e. late January, middle April, and late October to early November 2013, respectively), whereas number 9 indicates the sample reference for the time interval during which enhanced fluxes of E. huxleyi occurred at station M2 (i.e. early March 2013).

spp. in opposition to G. flabellatus and SST. Whereas both groups of variables do not show a clear seasonal pattern throughout the study period, they indicate contrasting ecological conditions between M2 and M4. The first group was clearly more associated with station M2 during the entire year, particularly during spring (most negative score in late March 2013), whereas the second group was persistently more associated with station M4 (most positive scores in November 2012 and later from May to September 2013). 
Table 2. Annual mean and range of coccolith fluxes and relative abundances of the most abundant coccolithophore taxa (mean $>2 \%$ ) for mooring stations M4 (left) and M2 (right). Loadings marked in bold refer to the strongest significant correlations $(r \geq 0.4)$.

\begin{tabular}{|c|c|c|c|c|c|c|c|c|}
\hline \multirow[t]{3}{*}{ Taxa } & \multicolumn{4}{|c|}{ Coccolith fluxes (coccoliths $\mathrm{m}^{-2} \mathrm{~d}^{-1} \times 10^{7}$ ) } & \multicolumn{4}{|c|}{ Relative abundances (\%) } \\
\hline & \multicolumn{2}{|c|}{ M4 } & \multicolumn{2}{|c|}{$\mathrm{M} 2$} & \multicolumn{2}{|r|}{ M4 } & \multicolumn{2}{|c|}{ M2 } \\
\hline & Mean & Min-Max & Mean & Min-Max & Mean & Min-Max & Mean & Min-Max \\
\hline Total fluxes & 247 & $117-423$ & 66 & $25-153$ & & & & \\
\hline \multicolumn{9}{|l|}{ UPZ TAXA } \\
\hline G. oceanica & 4 & $0.2-26$ & 0.3 & $0-1$ & 2 & $0.1-9$ & 0,4 & $0-2$ \\
\hline E. huxleyi & 17 & 4-69 & 4 & $1-14$ & 7 & $3-21$ & 5 & $3-13$ \\
\hline G. muellerae & 7 & $0-72$ & 0.2 & $0-1$ & 3 & $0-25$ & 0.3 & $0-1$ \\
\hline Helicosphaera spp. & 2 & $0.1-6$ & 2 & $1-4$ & 1 & $0.1-2$ & 3 & $1-9$ \\
\hline Rhabdos. spp. & 4 & $0-11$ & 2 & $0.3-5$ & 1 & $0-3$ & 2 & $1-5$ \\
\hline Umbellos. spp. & 9 & $3-16$ & 5 & $1-11$ & 4 & $2-8$ & 7 & $4-10$ \\
\hline Umbilico. spp. & 4 & $2-9$ & 1 & $0.3-3$ & 2 & $1-3$ & 2 & $1-3$ \\
\hline \multicolumn{9}{|l|}{ LPZ TAXA } \\
\hline$R$. sessilis & 2 & $1-5$ & 2 & $0.4-3$ & 1 & $0.2-2$ & 3 & $1-4$ \\
\hline F. profunda & 97 & $51-235$ & 39 & $14-90$ & 39 & $29-56$ & 60 & $53-72$ \\
\hline G. flabellatus & 85 & $36-146$ & 6 & $2-24$ & 35 & $18-47$ & 9 & $4-16$ \\
\hline
\end{tabular}

Factor $2(\mathrm{~F} 2-16 \%)$ is represented by precipitation, SST, and $\mathrm{Chl} a$ in opposition to SSS, AOD, PAR, and to a lesser extent, wind and Helicosphaera spp. The two groups of variables showed a similar seasonal pattern at both stations, with precipitation, SST, and Chl $a$ displaying a stronger negative signal during the fall months, particularly at M4 (most negative score in October 2013). The second group was most strongly correlated during spring and early summer at both stations (most positive scores in late May and early June 2013; Fig. 7, Table 3).

Factor $3(\mathrm{~F} 3,10 \%)$ is represented by G. muellerae and to a lesser extent G. oceanica, in opposition to Rhabdosphaera spp., Umbilicosphaera spp., PAR, and to a lesser extent, Umbellosphaera spp. The latter group revealed little statistical significance throughout the year at either location (i.e. scores close to zero) except in January 2013 when G. muellerae recorded high negative scores at station M4 (Fig. 7, Table 3).

Factor $4(\mathrm{~F} 4,8 \%)$ reflects $F$. profunda in opposition to E. huxleyi, G. oceanica, and to a lesser extent, wind speed. F4 reveals a weak signal at both locations during most of the year, except in April and October 2013 when two sharp positive peaks at station M4 reflected the short-term and sharp increases in E. huxleyi and G. oceanica. Relatively minor but still significant positive peaks occurred in January at M4 and in March at M2. Negative peaks were recorded in November 2012 at both stations, later in early May at M4, and in late August 2013 at both stations, reflecting the higher presence of $F$. profunda during these periods (Fig. 7, Table 3).

\section{Discussion}

\subsection{Similar temporal variations in the tropical flora in the western and central equatorial North Atlantic}

Comparable seasonal patterns in total coccolith fluxes observed at stations M4 and M2 point to similar environmental background conditions during the sampling period at both sites (Figs. 3 and 4). This is better expressed in Factor 2 (explaining $16 \%$ of the variance), showing that the overall atmospheric and oceanographic conditions did not vary considerably between the two locations (Fig. 7). In the tropical North Atlantic, meteorological conditions are mostly controlled by seasonal variations in the trade winds and the Intertropical Convergence Zone (ITCZ), the latter being a zone of low pressure and increased cloudiness and precipitation near the Equator (e.g. Oschlies and Garçon, 1998). The ITCZ migrates in latitude during summer and winter months in the Northern Hemisphere, shifting on average between $5^{\circ} \mathrm{S}$ during January and $12^{\circ} \mathrm{N}$ during July (e.g. Basha et al., 2015; see Fig. 8). Maxima in coccolith flux in OctoberNovember 2012 and July 2013 (Figs. 3 and 4) appear to have occurred under the direct influence of the ITCZ. This was especially the case in the fall months, as revealed by the prevailing high precipitation rates, weaker winds, and low PAR conditions during this period (Figs. 2c, d and 7; F2 negative scores). Whereas persistently high SSTs can be interpreted as an indicator of the generally stratified conditions typical of tropical open-ocean regions (e.g. Mann and Lazier, 2006; Haidar and Thierstein, 2001), the highest temperature values during the fall of 2012 and from mid-summer to the fall of 2013 suggest that stratification was the strongest under the influence of the ITCZ, probably reflecting the weakening of 


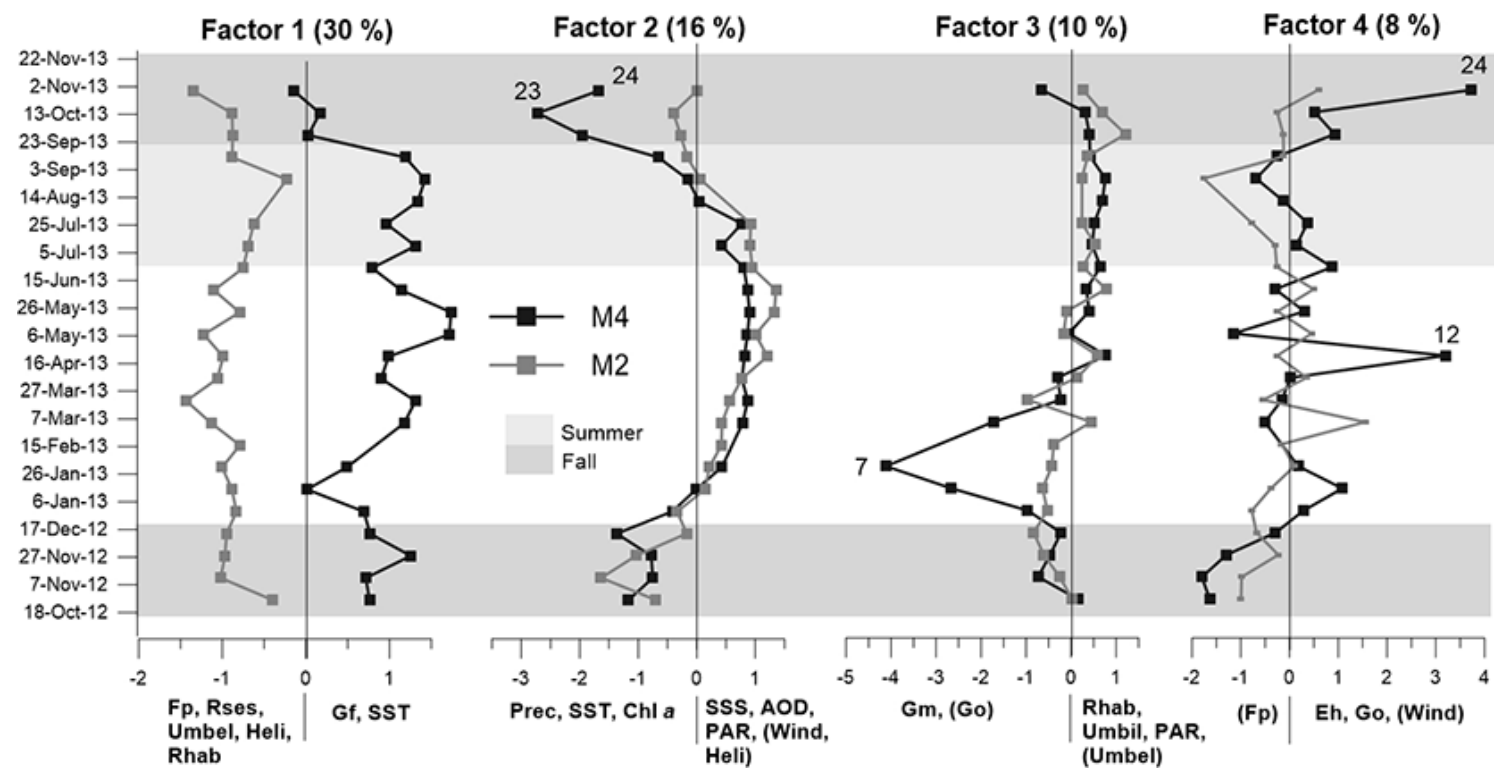

Figure 7. Spatio-temporal variation in the scores obtained from factor analysis. For taxonomical references, see Table 3.

the winds during these periods. The highest coccolith fluxes recorded under these conditions suggest that higher stability of the photic layer favoured the development and/or the settling of coccolithophores during these periods. In contrast, minima in coccolith flux during the winter-spring period occurred when the ITCZ was displaced further south of the study area, and hence surface circulation was mostly influenced by the NE trade winds and by the westward-flowing NEC (see Sect. 2). This appears to be reflected in the positive correlation between wind strength and high PAR (F2 positive scores) and the negative correlation between wind and precipitation (Fig. 7). SST minima and the intensification of the wind during winter and spring suggest that deepening of the mixed layer due to winter cooling combined with some wind-forced vertical mixing (Fig. 2a, b, e, and f) could have resulted in some nutrient entrainment from below (see Sect. 5.2.2). The lowest coccolith fluxes under these conditions seem to indicate that enhanced wind-forced mixing was less favourable to the productivity and/or downward transfer of coccoliths compared to the more stable conditions in the fall and summer.

Comparable seasonal developments in total coccolith export fluxes at stations M2 and M4 were also reflected in the species composition. A predominantly tropical assemblage was found throughout the investigated period in both areas (Figs. 5 and 6), in general agreement with previous studies from nearby tropical and subtropical areas (Kinkel et al., 2000; Haidar and Thierstein, 2001; Winter et al., 2002; Boeckel and Baumann, 2008; Poulton et al., 2017). It included species considered well adapted to the highnutrient and low-light conditions prevailing in the LPZ, such as $F$. profunda, G. flabellatus, and $R$. sessilis (e.g. Okada and Honjo, 1973; Young, 1994; Haidar and Thierstein, 2001; Winter et al., 2002), and taxa that are more often found in the nutrient-depleted and well-illuminated UPZ, such as Umbellosphaera spp., Rhabdosphaera spp., and Umbilicosphaera spp. (e.g. Winter et al., 1994, 2002; Young, 1994; Haidar and Thierstein, 2001). The presence of taxa with a higher affinity for mesotrophic conditions, such as Helicosphaera spp. (Haidar and Thierstein, 2001; Boeckel et al., 2006; Ziveri et al., 2004), and species with affinity with more turbulent and eutrophic environments, such as E. huxleyi, G. muellerae, and G. oceanica (e.g. Winter et al., 1994, 2002; Kinkel et al., 2000; Guerreiro et al., 2013), point to occasionally enhanced environmental variability promoting nutrient input, as discussed in Sect. 5.2.2.

In terms of seasonal patterns, however, little is known about the living coccolithophore communities thriving in the tropical Atlantic. In the subtropical Atlantic near Bermuda, $2200 \mathrm{~km}$ further north, seasonal variability appears more pronounced with the highest standing stocks from winter to spring and the lowest during summer (Haidar and Thierstein, 2001). This is opposite to our observations in the tropical Atlantic showing coccolith flux maxima during fall and summer (Figs. 3 and 4). Species relative proportions are different as well; whereas the subtropical Bermuda living coccolithophore community was largely dominated by the fastblooming E. huxleyi, the settling coccolith assemblages at stations M4 and M2 were persistently dominated by the LPZ species F. profunda and G. flabellatus (Fig. 5). The difference between the two areas appears to reflect the much stronger winter cooling, vertical mixing, nutrient entrainment, and summer stratification in the subtropical Atlantic off Bermuda compared to the more oligotrophic and persistently strati- 

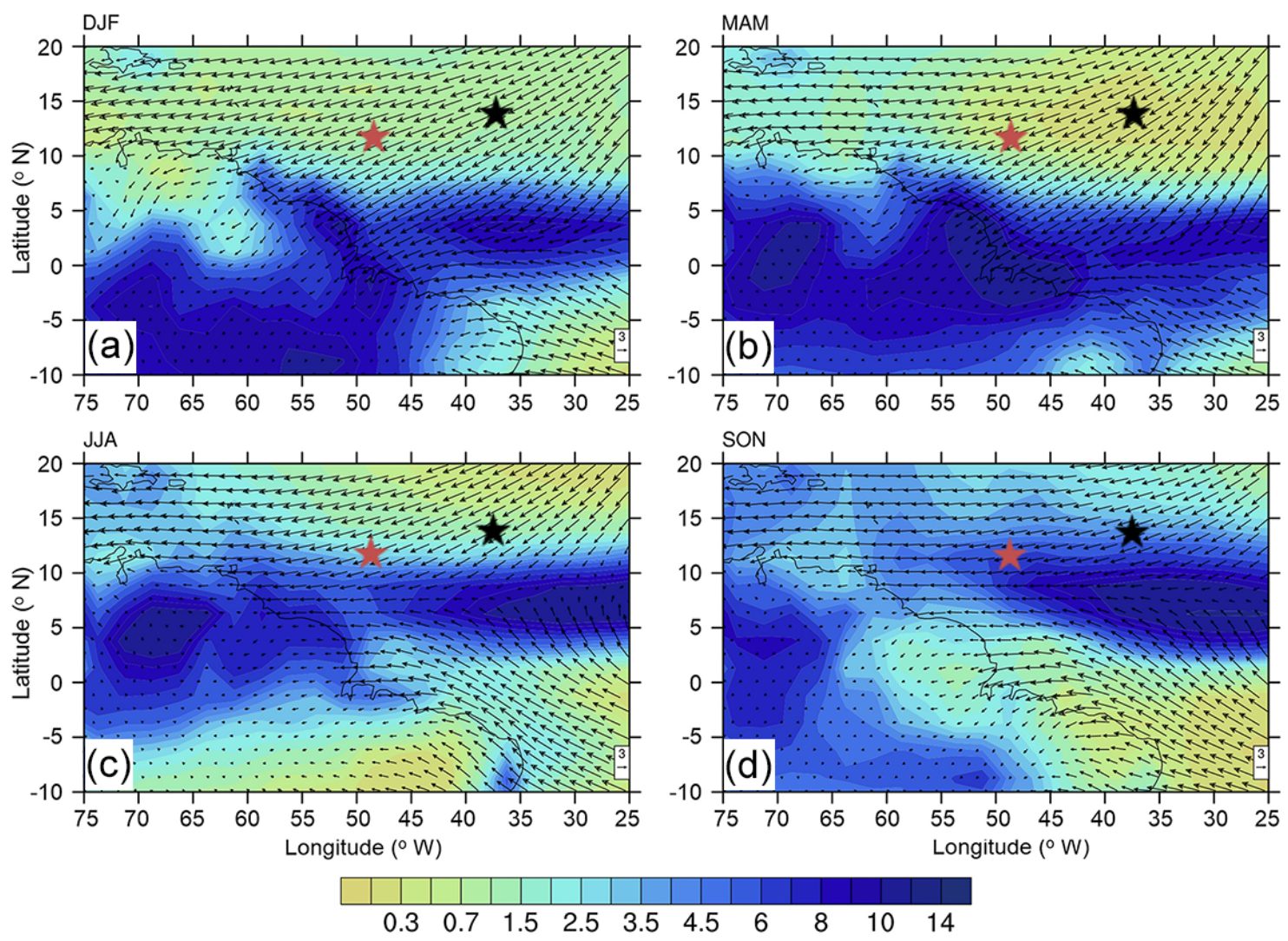

Figure 8. Climatological seasonal means of wind (speed and direction; reference vector length: $3 \mathrm{~ms}^{-1}$ ) and precipitation rates (colour shading; mm/day) over the central-western equatorial Atlantic Ocean for boreal (a) winter (December-February), (b) spring (March-May), (c) summer (June-August), and (d) autumn (September-November) illustrating the seasonal latitudinal migrations of the Intertropical Convergence Zone (ITCZ). Wind data (years: 1988-2015) were obtained from the CCMP Ocean Surface Wind Vector Analyses (Atlas et al., 2011) and precipitation data (years: 1979-2015) from the CPC Merged Analysis of Precipitation (CMAP; Xie and Arkin, 1997). Red and black stars refer to the location of sites M4 and M2, respectively.

fied conditions in the tropical Atlantic (Molfino and McIntyre, 1990; Haidar and Thierstein, 2001; Mann and Lazier, 2006 and references therein). Nevertheless, higher coccolith and coccosphere concentrations of $F$. profunda $(\sim 30$ 100 liths per sphere; Okada and Honjo, 1973) and possibly also G. flabellatus compared to E. huxleyi ( 9-50 liths per sphere; Cros and Fortuno, 2002) could result in overestimation of their abundance in the traps. This means that the dominance of the LPZ flora in the settling coccolith assemblages from the equatorial North Atlantic may not necessarily reflect overwhelmingly higher productivity compared to E. huxleyi but simply a high production rate combined with higher settling of coccoliths per cell.

That $F$. profunda and G. flabellatus revealed similar seasonal patterns and the highest abundances during strong stratification conditions in fall and summer, which is consistent with observations from the open subtropical North Atlantic (Haidar and Thierstein, 2001; Broerse et al., 2000; Fig. 6a and $b$ ). The increase in both fluxes and percentages during fall at both stations appears to reflect their better adaptation to high stratification conditions and lower light intensities com- pared to other species. Conversely, the increase in several UPZ tropical species within Umbellosphaera spp., Rhabdosphaera spp., Helicosphaera spp., and Umbilicosphaera spp. during summer appears to be related to slightly higher PAR levels during this period (Figs. 2c, $d$ and 7). The general affinity of Umbellosphaera spp., Rhabdosphaera spp., and Umbilicosphaera spp. for stratified and well-illuminated conditions was also evidenced by their higher percentages and positive correlation with PAR from late spring to early fall at both stations (F3; Fig. 7). This is also consistent with previous studies from other tropical and subtropical areas in the North Atlantic (Haidar and Thierstein, 2001; Kinkel et al., 2000; Winter et al., 2002; Poulton et al., 2017).

\subsection{Spatial variations in coccolith fluxes: western vs. central equatorial North Atlantic}

In spite of similar seasonal developments in both coccolith fluxes and species composition, stations M2 and M4 revealed striking differences in export fluxes by most species, pointing to the influence of environmental factors that are specific to 
Table 3. Factor loadings (varimax raw), eigenvalues, and percentage of the explained variance extracted from the data matrices referring to the period from October 2012 to October-November 2013 at stations M4 and M2 ( $r$-mode factor analysis by Statistica 13; marked loadings are $>0.4)$. Chl $a$ - surface phytoplankton biomass, SST and SSS - sea surface temperature and salinity, PAR - photosynthetic available radiance, AOD - aerosol optical depth, Prec daily precipitation rate, and Wind - wind speed. In Factor 3, numbers 7 and 12 indicate the sample reference for the time intervals during which G. muellerae and E. huxleyi produced "pulse-like" maxima at station M4 (i.e. late January and middle April 2013, respectively; see Fig. 6i and c), whereas in Factor 4, number 24 indicates the sample reference for the time interval during which the pulse-like maxima of sea surface Chl $a$ and $G$. oceanica, together with a sharp increase in E. huxleyi, occurred at station M4 (i.e. late October to early November 2013; see Fig. 6c and j). In Factor 2, numbers 23 and 24 indicate the time intervals during which SSS minima were recorded during fall at the same site (see Fig. 2).

\begin{tabular}{lrrrr}
\hline & $\mathrm{F} 1$ & $\mathrm{~F} 2$ & $\mathrm{~F} 3$ & $\mathrm{~F} 4$ \\
\hline F. profunda (Fp) & $-\mathbf{0 . 8}$ & 0.2 & 0.1 & $-\mathbf{0 . 4}$ \\
G. flabellatus (Gf) & $\mathbf{0 . 9}$ & -0.2 & 0 & 0 \\
E. huxleyi (Eh) & 0.2 & 0.1 & 0.2 & $\mathbf{0 . 8}$ \\
Umbellosphaera spp. (Umbel) & $-\mathbf{0 . 7}$ & -0.2 & $\mathbf{0 . 4}$ & -0.1 \\
Rhabdosphaera spp. (Rhab) & $-\mathbf{0 . 5}$ & 0 & $\mathbf{0 . 6}$ & 0.2 \\
Helicosphaera spp. (Heli) & $\mathbf{- 0 . 6}$ & $\mathbf{0 . 4}$ & 0.2 & 0 \\
Umbilicosphaera spp. (Umbil) & -0.3 & 0.1 & $\mathbf{0 . 5}$ & 0.2 \\
R. sessilis (Rses) & $-\mathbf{0 . 8}$ & 0 & 0.1 & -0.2 \\
G. muellerae (Gm) & 0.2 & 0.1 & $-\mathbf{0 . 8}$ & 0.1 \\
G. oceanica $(\mathrm{Go})$ & 0.2 & -0.2 & $-\mathbf{0 . 4}$ & $\mathbf{0 . 6}$ \\
Chl $a$ & 0 & $-\mathbf{0 . 5}$ & 0 & 0.2 \\
SST & $\mathbf{0 . 5}$ & $-\mathbf{0 . 7}$ & 0.1 & -0.1 \\
PAR & 0.2 & $\mathbf{0 . 5}$ & $\mathbf{0 . 5}$ & 0.1 \\
AOD & -0.2 & $\mathbf{0 . 6}$ & 0.2 & 0 \\
SSS & -0.1 & $\mathbf{0 . 8}$ & 0.2 & -0.1 \\
Prec & 0.1 & $-\mathbf{0 . 8}$ & 0.2 & 0 \\
Wind & 0 & $\mathbf{0 . 4}$ & -0.3 & $\mathbf{0 . 4}$ \\
Eigenvalues & 3.8 & 3.2 & 2.1 & 1.6 \\
Expl. Var. (\%) & 30 & 16 & 10 & 8 \\
\hline
\end{tabular}

each location. Below we highlight the main differences between the two areas and discuss the factors that potentially trigger them.

\subsubsection{Higher productivity and/or transfer efficiency of the LPZ flora at the western site M4}

Fluxes recorded at station M4 were high not only in comparison to station M2, but also to several other locations in the Atlantic Ocean, including open-ocean temperate and subtropical settings (e.g. Knappertsbusch and Brummer, 1995; Broerse et al., 2000; Sprengel et al., 2002), areas in the vicinity of islands (Sprengel et al., 2002), and more marginal regions, even when under the influence of coastal upwelling (Beaufort and Heussner, 1999; Köbrich and Baumann, 2009). Furthermore, most of these flux studies referred to the opportunistic $E$. huxleyi as being the dominant species, while the unexpectedly high total coccolith fluxes we found in the presumably oligotrophic western equatorial North Atlantic were mostly due to the LPZ dwellers $F$. profunda and G. flabellatus. Mean fluxes of G. flabellatus, in particular, were almost 14 times higher at M4 than at M2 (Fig. 6b, Table 2) and contributed importantly to Factor 1, explaining the highest percentage of the variability within the taxa and environmental parameters (i.e. $30 \%$ ) compared to the other factors $(16,10$, and $9 \%$ for $\mathrm{F} 2, \mathrm{~F} 3$, and F4, respectively; Fig. 7). That F1 is clearly characterized by the opposition between the central station M2 and the western station M4 highlights the much higher abundances of $G$. flabellatus further west as the most important feature or difference between the two sites and indicates the presence of spatial variability shown by the LPZ flora as the statistically more relevant factor explaining our flux records. This finding is consistent with what it is known about the well-constrained enhancement of this species in surface sediments from the western equatorial Atlantic and Brazilian continental margin (Kinkel et al., 2000; Boeckel et al., 2006). That Umbellosphaera spp., Rhabdosphaera spp., Umbilicosphaera spp., E. huxleyi, and gephyrocapsids also produced higher coccolith fluxes in this area points to enhanced productivity throughout the entire photic zone at M4.

The persistent and overwhelming dominance of the LPZ flora suggests profiting from some subsurface and year-round nutrient supply. Forced by the trade winds, the westward deepening of the equatorial mixed layer and associated nutricline (see Hastenrath and Merle, 1987; Longhurst, 1993; Philander, 2001) could have promoted higher production of the LPZ flora in the western equatorial Atlantic (Fig. 10). In situ CTD and nutrient measurements at both stations do indicate a consistently deeper nutricline at M4, particularly during spring when the deep chlorophyll maximum (DCM) was found deeper at station M4 compared to station M2 (data not shown; Roepert and Brummer in Stuut et al., 2016).

In addition to the westward tilting of the nutricline, changes in the depth range of the Antarctic Intermediate Water (AAIW) flowing in from the south-west (Reid, 1994) may have also contributed to the enhanced fluxes of the LPZ flora further west (see http://whp-atlas.ucsd.edu and Fig. 10). Originating from the surface region of the Antarctic circumpolar layer, this water mass is known to follow the South Atlantic subtropical gyre to enter the western equatorial Atlantic (Stramma et al., 2003; Stramma and England, 1999). It crosses the Equator and spreads along the Brazilian shelf (Talley, 1996), contributing high nutrients and low oxygen to the Gulf Stream and North Atlantic Current (Reid, 1994). Furthermore, Poulton et al. (2017) have recently reported that F. profunda and Gladiolithus spp. thrive below the depth at which light is thought to be sufficient to support photosynthesis in equatorial waters, probably by mechanisms of mixotrophy and/or phagotrophy. This means that these two species may be able to live even deeper in the water column than originally thought. 
Higher fluxes at station M4 may also be related to the higher production of faecal pellets by zooplankton grazers acting as vehicles for the downward flux of coccolithophores in this area. Recent observations by Knebel (2016) report higher fluxes of spinose planktonic foraminifera at station M4 compared to M2. Knappertsbusch and Brummer (1995) argued earlier that the export of coccolithophores is intimately related to day-to-day fluctuations in faecal pellet production by migrating zooplankton and nekton in the overlying mesopelagic zone. Therefore, higher zooplankton grazing in the western equatorial North Atlantic may have increased the coccoliths' transfer efficiency, hence contributing to the much higher coccolith fluxes compared to the central equatorial North Atlantic (Fig. 10).

\subsubsection{Transient productivity of the $r$-selected UPZ flora at the western site M4}

Spatial environmental variability in the equatorial North Atlantic is most clearly expressed by the much higher fluxes and the pulsed maxima of the more opportunistic species E. huxleyi, G. muellerae, and G. oceanica at station M4 compared to their persistently low abundances and weak seasonality at station M2 (Figs. 6c, i, j, and 5). Their occurrence in the form of short-term high-flux events in January, April, and October-November 2013 at station M4 was associated with strikingly increasing ratios between these species and the LPZ flora (Fig. 9). Stoll et al. (2007) have used similar ratios as indicators of upwelling in the Bay of Bengal based on the idea that the decrease in the LPZ flora reflects the shallowing of the nutricline (Molfino and McIntyre, 1990; Beaufort et al., 1997). The sporadic sharp increase in the UPZ/LPZ ratio at station M4 hence suggests that the nutricline was temporarily shallower, resulting in a fast production response of the more opportunistic placolith-bearing species to increased nutrient input. Higher fluxes of these UPZ taxa at station M4 support the argument that the equatorial North Atlantic becomes generally more productive further west.

\section{Influence of wind-forced water mixing and dispersal of the Amazon River Plume}

The pronounced maximum of G. muellerae in January 2013 (samples M4-6 and M4-7; Figs. 6i and 9a) was strong enough to be reflected in Factor 3, explaining $10 \%$ of the variance (Fig. 7). This event occurred when the wind had just started to intensify and PAR was gradually increasing, as expected from the fall-winter transition in the equatorial North Atlantic (Fig. 2). This probably resulted in some degree of vertical mixing, as suggested by the decrease in SST, which in turn may have led to the supply of nutrients from below the pycnocline to shallower levels in the photic zone (see Sect. 5.1). The lack of a significant response by E. huxleyi and $G$. oceanica during this period suggests that nutrient availability was lower and/or not persistent enough for these species to bloom. Previous studies reported G. muellerae to have an affinity for intermediate to higher nutrient conditions in more transitional water conditions where competition with E. huxleyi and G. oceanica is lower (e.g. Giraudeau and Bailey, 1995; Boeckel et al., 2006; Guerreiro et al., 2013) and to occupy a deeper position in the photic zone than other species of the genus Gephyrocapsa (Boeckel and Baumann, 2008; Guerreiro et al., 2013). Low surface Chl $a$ concentrations (Fig. 9a) and the absence of any significant increase in biogenic mass fluxes during this January period (Korte et al., 2017; Fig. 9b) point to a scenario in which only a few species profit from short-term nutrient supply and moderate light intensities at intermediate levels in the photic zone.

Similar conditions appear to have recurred in April 2013 (sample M4-12), with a pulsed maximum of E. huxleyi occurring under maximum PAR and lower SST following a period of more persistent wind strength increase that lasted from early winter until late spring (Figs. 2, 6c, and 9). This suggests that the water masses were stratified enough but still nutrient enriched due to previous wind-forced vertical mixing, hence promoting favourable conditions for blooming species to rapidly develop in the UPZ. The observed response of E. huxleyi is consistent with previous observations from other open-ocean areas reporting this species to dominate spring coccolithophore blooms (Haidar and Thierstein, 2001) and to induce enhanced coccolith fluxes (Broerse et al., 2000; Sprengel et al., 2002) following the water mixing and concomitant nutrient replenishment of the photic zone typical of late winter and early spring. That $E$. huxleyi responded in April but not in January suggests that it was more efficiently growing under presumably higher nutrient availability and maximum light levels during spring. This is consistent with previous observations of E. huxleyi bursting into a bloom within only a few days in response to nutrient availability and clear sky conditions in surface waters (Guerreiro et al., 2013). The high tolerance of this species to high levels of light has been considered crucial for its capacity to dominate coccolithophore assemblages (Nanninga and Tyrrell, 1996; Tyrell and Merico, 2004). Although to a lesser extent compared to E. huxleyi, other taxa that also increased during this April period include Helicosphaera spp., Rhabdosphaera spp., and Umbilicosphaera spp. This event was strong enough to be reflected in Factor F4, explaining $8 \%$ of the variance (Fig. 7) in enhanced total coccolith fluxes and species $H^{\prime}$ (Fig. 3), and by a striking flux increase in $\mathrm{CaCO}_{3}$, organic matter, and biogenic silica (Korte et al., 2017; Fig. 9b). This suggests that nutrient and light conditions were sufficiently favourable and persistent enough to promote the development of the entire UPZ plankton community during this short period.

The pulsed maxima of $G$. oceanica and E. huxleyi in October-November 2013 (sample M4-24) were also strong enough to be revealed by Factor 4 (Fig. 7) and by a slight increase in the total coccolith export production (Figs. 3 and 6c, j). Higher fluxes of these species were accompanied by in- 

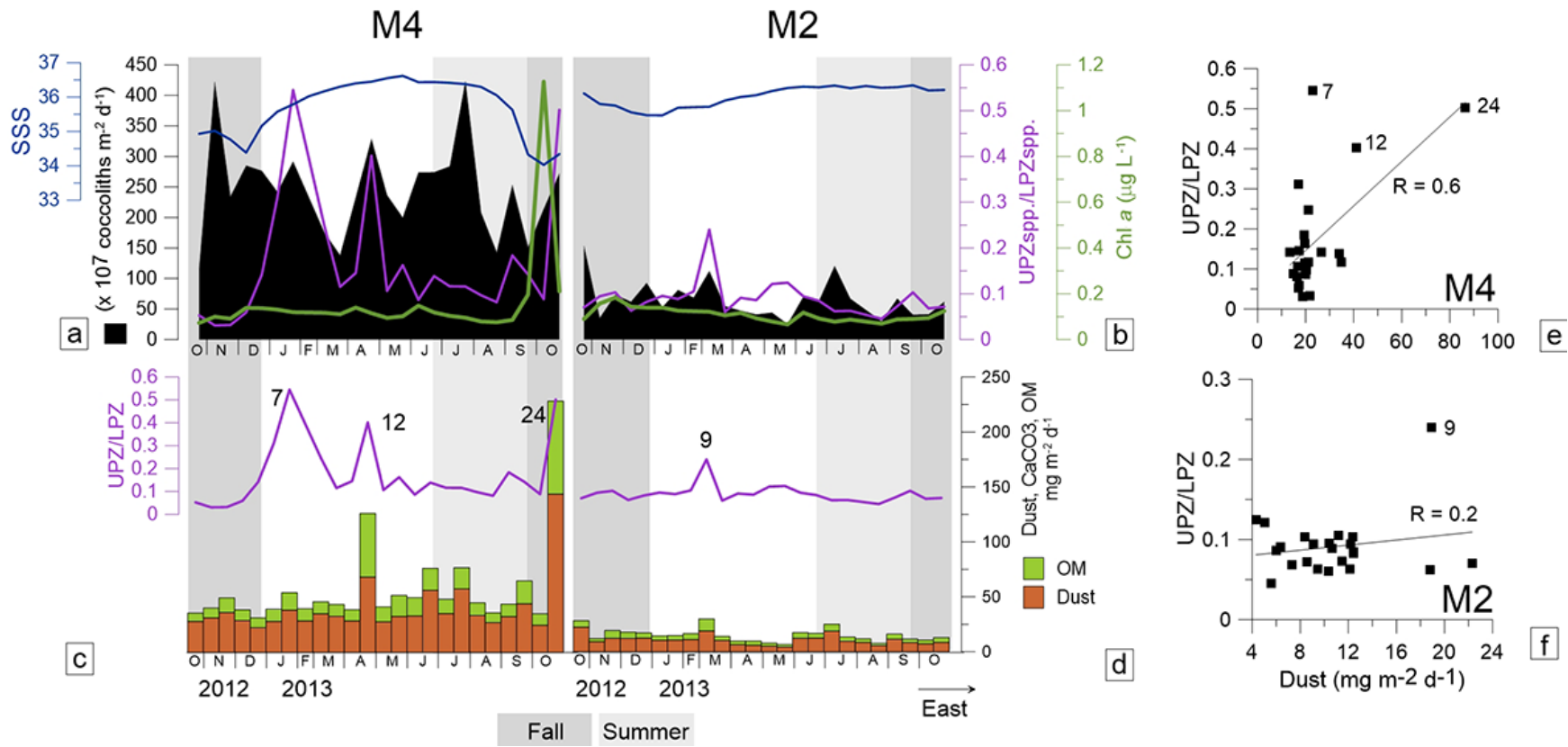

Figure 9. (a, b) Seasonal variation in total coccolith fluxes (black), sea surface salinity (SSS; dark blue), Chl $a$ concentrations (green), and UPZ / LPZ ratio (purple) calculated from the sum of the fluxes by G. muellerae, G. oceanica, and E. huxleyi divided by the sum of the fluxes by F. profunda and G. flabellatus; (c, d) fluxes of dust inferred from the residual lithogenic fraction (orange bars) and organic material (OM, green bars) recently published by Korte et al. (2017); (e, f) correlation between UPZ/LPZ and the dust. Dark and light grey bands refer to fall and summer, respectively.

creased surface $\mathrm{Chl} a$ concentrations (Fig. 9a), pointing to high productivity in the uppermost photic zone (Figs. $6 \mathrm{c}, \mathrm{j}$ and 9a). During the SEM counting of coccoliths throughout sample M4-24, extremely high amounts of large diatom fragments were found, strongly supporting a scenario in which nutrient enrichment at the surface and clear sky conditions promoted the development of more competitive phytoplankton species. This is further supported by a striking flux increase in organic matter, biogenic silica, and to a lesser extent, $\mathrm{CaCO}_{3}$ during the same period (Korte et al., 2017; Fig. 9b). The ability of E. huxleyi and G. oceanica to compete with diatoms in surface waters and to rapidly respond to nutrient availability was observed in coastal waters off central Portugal, confirming its capacity for rapid population growth in nutrient-rich environments (Guerreiro et al., 2013).

During the fall 2013 event, SSS had dropped to a minimum of 33.9 at station M4 compared to $\sim 36.25$ recorded at station M2 during the same period (Figs. 2a, b and 9a, b). Since both areas are under the influence of the ITCZ with a comparable precipitation regime (see Fig. 8) and given that higher precipitation during the fall of 2012 at M2 was associated with much higher SSS than at M4 for the same period (Fig. 2c and d), the distinctly lower salinity at M4 in October-November 2013 likely reflected advected Amazon River water (Figs. 9 and 10). A strong positive correlation between high surface $\mathrm{Chl} a$ concentrations and the salinity minimum revealed by Factor 2 (Fig. 7) along with the sharp increase in surface-dwelling opportunistic species, biogenic silica, and organic matter during this period (Fig. 9; Korte et al., 2017) suggest that this nutrient-rich buoyant plume promoted the development of phytoplankton at the surface of the western equatorial North Atlantic. The presence of the plume at station M4 was also noticed in a CTD profile taken during the recovery of the sediment trap mooring in late November 2013, showing a relatively shallow chlorophyll maximum associated with Amazon-related phytoplankton productivity (unpublished data, not shown). Previous satellite observations from this area have shown the north-eastward dispersion of the Amazon River Plume forced by the NBC retroflection at around $5-10^{\circ} \mathrm{N}, 50^{\circ} \mathrm{W}$, typically from August to December (e.g. Muller-Karger et al., 1988; Molleri et al., 2010; see Sect. 2). The plume resulted in a dramatic surface salinity contrast (Wilson et al., 1994) and promoted a gradient in environmental conditions that evolved while the plume was meandering northward and mixing with the open-ocean waters, with a strong impact on the magnitude and composition of phytoplankton communities (refs. in Goes et al., 2014). The influence of the Amazon River water on the living coccolithophore communities has been previously reported by Winter et al. (2002) in the Caribbean Sea where enhanced cell densities of E. huxleyi and G. oceanica were seen coupled with this buoyant water mass. Our trap record clearly testifies to its impact by changing the flux and species composition of the coccolithophore communities in 

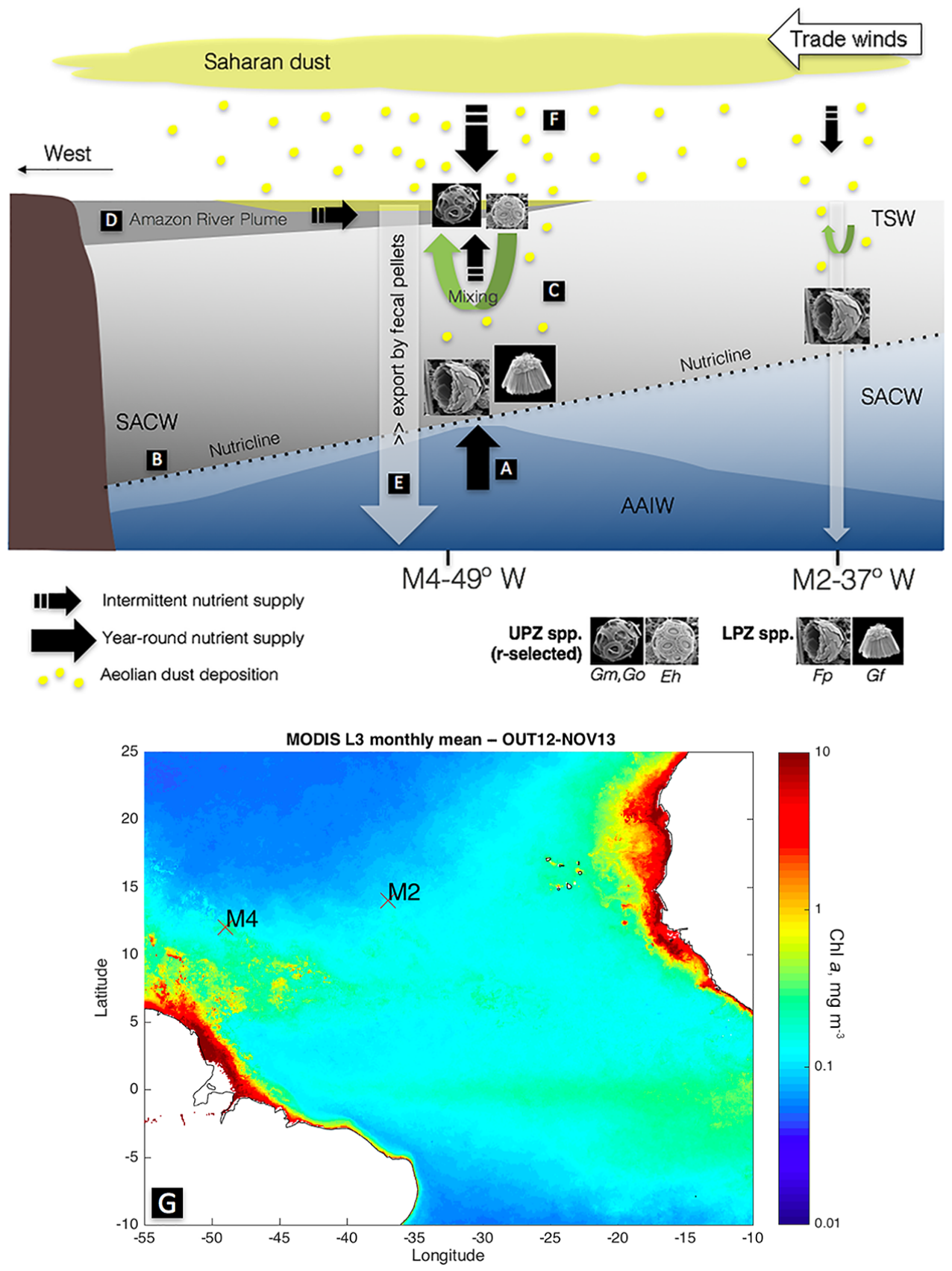

Figure 10. Schematic figure summarizing the main environmental mechanisms interpreted as being at the origin of the ecological contrasts observed between stations M4 and M2 from October 2012 to October-November 2013: (A) nutrient supply by AAIW depth range oscillations (dark blue lowermost layer) combined with (B) nutricline E-W basin-scale tilting (dashed black line), promoting the development of the LPZ species G. flabellatus and $F$. profunda further west; (C) wind-forced surface ocean mixing and (D) eastward dispersion of the Amazon River Plume, resulting in transient "pulse-like" increases in the opportunistic UPZ species E. huxleyi, G. muellerae, and G. oceanica; (E) higher production of faecal pellets by zooplankton grazers (white vertical arrow) at M4 contributing to increase the coccolith export efficiency; (F) Saharan dust deposition (yellow dots) influencing the study area, particularly at M4 where the Amazon River Plume acts as a surface density retainer of nutrients settling from the atmosphere; $(\mathrm{G})$ sea surface $\mathrm{Chl} a$ concentrations averaged for the sampling period in the equatorial Atlantic Ocean illustrating the contrast between higher and lower surface productivity at stations M4 and M2, respectively. Abbreviations: UPZ - upper photic zone; LPZ - lower photic zone; E. huxleyi - Eh; G. muellerae - Gm; G. oceanica - Go; Fp - F. profunda; Gf G. flabellatus; TSW - tropical surface water; SACW - South Atlantic Central Water; AAIW - Antarctic Intermediate Water. 
the oligotrophic western equatorial North Atlantic. Furthermore, despite the limitations of using environmental data that only represent the atmospheric conditions and the surface of the ocean, it highlights the remarkably good statistical correlation between surface satellite data (i.e. drastic salinity decrease and associated increase in Chl $a$ ) and enhanced coccolith fluxes of G. oceanica, E. huxleyi, organic matter, and biogenic silica (Korte et al., 2017) in the trap at $1200 \mathrm{~m}$ of depth.

\section{Influence of Saharan dust deposition}

The present-day deposition of Saharan dust has been recently quantified based on a transatlantic array of four sediment trap moorings between NW Africa and the Caribbean, which included mooring traps M4 and M2 (Korte et al., 2017; van der Does et al., 2016). The increase in AOD from spring to mid-summer at both stations (Fig. 2e and f) and its positive correlation with wind speed during this time (F2 positive scores; Fig. 7) corresponds to the same period when Korte et al. (2017) found the best accordance between dust outbreaks detected from satellite and high fluxes of dustdriven lithogenic particles. This agrees with previous observations that transatlantic Saharan dust fluxes are the highest during summer (e.g. Prospero et al., 2014). Since precipitation started to increase at the beginning of July at both stations (Fig. 2c and d), wet dust deposition probably contributed to the observed enhanced coccolith fluxes (Figs. 3 and 4). Through the exposure of the dust particles to cloud processes and mixing with anthropogenic species such as $\mathrm{HNO}_{3}$ in the atmosphere, wet dust deposition is thought to provide more bioavailable (soluble) nutrients compared to dry dust deposition and hence to have a greater fertilizing effect for primary production (Ridame et al., 2014). With the exception of $R$. sessilis, all the tropical taxa, including both UPZ and LPZ flora, showed increased fluxes during the July period at both locations, suggesting that coccolithophores benefited from the nutrient input by dust along the entire photic zone. A positive correlation between AOD and Helicosphaera species thought to thrive in waters of moderately high fertility (Roth and Bergen, 1975; Haidar and Thierstein, 2001; Boeckel et al., 2006) points to an ecological response to increased nutrient levels in July (F2; Fig. 7). Whereas E. huxleyi and G. oceanica also slightly increased during this period, one would expect these species to have a more significant response compared to the tropical assemblage. This was, however, not the case, suggesting that the dust acted more as a ballast than as a fertilizer during summer.

Two prominent dust flux peaks not detected by satellite were recorded in April and October-November of 2013 at station M4 (Korte et al., 2017), precisely when E. huxleyi and $G$. oceanica revealed a pulse-like increase in abundance (Figs. 6c, j and 9). This points to a scenario in which Saharan dust also acted as a nutrient fertilizer in this area in addition to surface-ocean mixing (spring) and the discharge and advection of the Amazon River Plume (fall). In fact, our observations suggest that the Amazon acted not only as a nutrient supplier during fall, but also as a buoyant surface density retainer of dust nutrients in the surface layer. Such a combination would explain the much higher fluxes of biogenic silica reported for this period by Korte et al. (2017) and the drastic increase in Chl $a$ at the surface of the ocean (Figs. 2a and 9a). A similar case was observed offshore of central Portugal where the stabilization of a river buoyant plume was seen providing optimum stratification and nutrient-rich conditions for phytoplankton to bloom at the surface, resulting in a striking increase in $\mathrm{Chl} a$ concentrations, E. huxleyi, G. oceanica, and long-chain diatoms within only a few days (Guerreiro et al., 2013). Given the huge amounts of Saharan dust continuously blown into and over the Atlantic Ocean (e.g. Prospero et al., 2014), one could argue that the massive algal blooms reported to occur in the western equatorial North Atlantic, until now interpreted as being solely associated with nutrients provided by the Amazon, could actually result from the combination of surface buoyancy and nutrients provided by atmospheric dust deposition. In addition, the fall event was also marked by high precipitation rates, possibly resulting in higher nutrient bioavailability by means of wet dust deposition. In contrast, the Amazon Plume was not yet present in the study area during spring and the nearly non-existent precipitation possibly resulted in comparably lower nutrient bioavailability by dry dust deposition (see Ridame et al., 2014). Such differences in atmosphericsea surface conditions between the two events apparently had an effect on phytoplankton species composition, resulting in higher development of several opportunist phytoplankton species during the fall and only E. huxleyi during spring.

The observed short-term shift from a more typically tropical ( $K$-selected) to a more opportunistic ( $r$-selected) settling coccolith assemblage during April and OctoberNovember 2013 at station M4 supports the dust fertilization hypothesis earlier proposed by Martin (1990) and later corroborated by observations from the Amazon Basin (Bristow et al., 2010), the Gulf of Mexico, and the coast of southern Florida (Lenes et al., 2012). High fluxes of organic material recently observed in a sediment trap in the North Atlantic subtropical gyre $\left(23^{\circ} \mathrm{N}, 41^{\circ} \mathrm{W}\right)$ have been associated with enhanced phytoplankton productivity resulting from stimulated nitrogen fixation by Trichodesmium species following the deposition of dust-derived nutrients (Pabortsava et al., 2017). The role of aeolian dust for nitrogen fixation in subtropical and tropical oligotrophic regions has been previously reported by several authors (e.g. Falkowski et al., 1998; Mills et al., 2004; Jickels et al., 2005 and refs. therein; Martino et al., 2014). In the tropical North Atlantic where phytoplankton communities are nitrogen limited, experiments conducted by Mills et al. (2004) have shown Saharan dust addition to stimulate nitrogen fixation in this area, presumably by supplying iron and phosphorous. This is supported by Baker et al. (2006), who reported soluble phosphorous concentra- 
tions to be the highest in Saharan aerosols from the North Atlantic. Guieu et al. (2014), on the other hand, report the importance of strong and short-term (pulse-like) dust deposition events for marine productivity in low-nutrient, lowchlorophyll (LNLC) areas, whereas Romero et al. (2011) add that when dust input is accompanied by turbulence (i.e. strong winds), its potential fertilizing effects on phytoplankton are prone to be amplified. This fits well with the episodic nature of the dust deposition events at station M4 and the fact that they were accompanied by some degree of wind intensification.

In spite of all this evidence, mineral dust deposition is also thought to increase carbon sequestration to the deep ocean by acting as a mineral ballast of sinking particles (Pabortsava et al., 2017). Van der Jagt et al. (2017) report more abundant and faster-sinking aggregates when formed from a natural plankton community that has been exposed to Saharan dust deposition compared to less abundant and slowersinking aggregates when formed without dust. The same authors argue that such dust-influenced aggregates would become heavily ballasted with lithogenic material at the surface and hence without scavenging any additional particles during their settling. This could at least partially explain why the dust peaks in spring and fall were marked by maxima of surface-dwelling species but not maxima of the deepdwelling species. To confirm whether the pulsed flux maxima of opportunistic species presented in our study truly reflected the response of living coccolithophores thriving in the overlying photic layer to such a combination of factors (ecological signal) or resulted from enhanced particle transfer efficiency (e.g. ballasting by dust; faecal pellet production by zooplankton grazers; Armstrong et al., 2002; Ziveri et al., 2007; Fischer and Karakas, 2009; Fischer et al., 2016), a comparison between settling coccolith assemblages and the living coccolithophore communities as well as with in situ atmospheric-oceanographic observations would be required.

Whereas the spring and fall $r$-selected pulse events were accompanied by a slight increase in the total coccolith export, such an increase was never as high as in the peaks of November 2012 and July 2013 (see Sects. 4.1 and 5.1). This suggests that $r$-selected transient productivity is comparably less important than tropical background productivity for the overall bulk coccolith export production in the equatorial North Atlantic. Our observations indicate that enhanced productivity and/or transfer efficiency in the LPZ in the context of highly stratified tropical regions may be at least as important from a long-term perspective as that of the fast-blooming taxa more often found at higher latitudes and within productive coastal neritic areas.

\subsubsection{Typical oligotrophic open-ocean conditions at the central site M2}

In contrast to station M4, persistently lower abundances of opportunistic coccolithophore species, in particular the gephyrocapsids, and the absence of major pulse-like increases in these species at station M2 point to comparably more stable and oligotrophic conditions in this area. A narrower range and lower values of the UPZ / LPZ ratios at station M2 suggest that the UPZ was more persistently stratified and nutrient depleted in the central equatorial North Atlantic (Fig. 9). An exception occurs in early March 2013 when an increase in the UPZ / LPZ ratio at M2 and a species composition similar to that recorded in April at M4 is observed. It coincides with a slight flux increase in dust and carbonate (Korte et al., 2017), suggesting that M2 was also subjected to some degree of wind-forced water mixing (Fig. 2c and d) combined with Saharan dust deposition (Fig. 9). There are no indications of influence from Amazon River water at M2, as revealed by persistently low Chl $a$ concentrations at the surface and low fluxes of opportunistic taxa during the fall of 2013 (Fig. 9a). Our observations suggest that, compared to M4, M2 was less affected by continental influences whether from Amazon River water or Saharan dust. The location of station M2, which is more central and $2^{\circ}$ further north than station M4 closer to the centre of the North Atlantic subtropical gyre, may have contributed to the more oligotrophic character of this station (Fig. 10).

That the evidence we found for ocean fertilization by Saharan dust is more significant at station M4 than at station M2 may be due to the presence of buoyant Amazon water retaining nutrients and phytoplankton near the surface at M4 and to higher wet dust deposition during fall 2013 at station M4 (e.g. Ridame et al., 2014; Fig. 2c and d). A longer distance to the dust source in Africa at M4 compared to M2 may have also contributed to increasing the bioavailability of dust-driven nutrients further west (see Stuut and Prins, 2014). This could also help explain the lack of clear evidence for dust fertilization in open-ocean regions west of Africa (see Fischer et al., 2016; Neuer et al., 2004) since aerosols sinking in these areas would not be fine and chemically processed enough to act as fertilizers.

\section{Conclusions}

Our study provides important insights into the environmental factors governing the spatio-temporal variability of coccolithophores in the equatorial North Atlantic and illustrates how this supposedly oligotrophic and stable open-ocean region actually reveals significant ecological variability. The main findings from our sediment trap study are as follows.

1. A predominantly tropical coccolith settling assemblage and a generally similar seasonality in total coccolith fluxes at the western station M4 and central station M2 point to comparable background environmental conditions at both sites. Flux maxima were associated with stronger stratification conditions under the influence of the Intertropical Convergence Zone (ITCZ) during summer and fall, whereas flux minima occurred during 
stronger NE trade winds and lower SSTs during winter and spring.

2. Low-light- and deep-nutricline-dwelling $F$. profunda and $G$. flabellatus dominated at both locations during the entire sampling period, especially during fall. Upper photic zone taxa such as Umbellosphaera spp., Rhabdosphaera spp., Helicosphaera spp., and Umbilicosphaera spp. were more abundant during summer.

3. In spite of the similar seasonal pattern, the two openocean locations in the oligotrophic equatorial North Atlantic revealed striking differences in coccolith export fluxes, species proportions, and oceanographic processes.

4. Total coccolith fluxes were almost 4 times higher at the western station M4 than at the central station M2, mostly due to $G$. flabellatus and F. profunda, although many other species showed higher fluxes year-round. We interpret this as resulting from (i) westward deepening of the north equatorial nutricline and nutrient supply by the Antarctic Intermediate Water (AAIW), both favouring the LPZ flora, and (ii) higher transfer efficiency, possibly by enhanced zooplankton grazing in this area.

5. Higher abundances and pulsed flux maxima of more opportunistic species at station M4 point to the occurrence of transient productivity in this area: (a) the increase in E. huxleyi in April reflected a fast ecological response to intermittent nutrient input promoted by sea surface cooling and wind-forced vertical mixing combined with dry dust deposition, whereas (b) pulsed maxima of E. huxleyi and G. oceanica in October-November reflected a response to surface nutrient enrichment derived from Amazon River discharge combined with wet dust deposition.

6. Enhanced surface buoyancy provided by the relatively less saline Amazon River Plume appears to have contributed through retaining dust-derived nutrients in the surface layer during the fall of 2013, promoting the development of several opportunistic phytoplankton groups in the western site M4.

7. In contrast, persistently low coccolith fluxes in the central site M2, in particular of more opportunistic species, and the absence of major $r$-selected pulsed maxima point to comparatively more stable and oligotrophic conditions prevailing in the centres of subtropical gyres.

Our findings (i) provide relevant evidence to support the hypothesis of Saharan dust acting as a fertilizer for marine phytoplankton in the Atlantic Ocean and (ii) highlight the importance of LPZ coccolithophore species in terms of coccolith export production in the tropical Atlantic, with possible implications for the global oceanic carbonate budget.
Data availability. Data are available at https://doi.org/10.1594/ PANGAEA.881485.

Competing interests. The authors declare that they have no conflict of interest.

\section{The Supplement related to this article is available online at https://doi.org/10.5194/bg-14-4577-2017-supplement.}

Acknowledgements. Moorings were deployed during RV Meteor cruise M89 and recovered after 1 year during RV Pelagia cruise 64PE378 by the Royal Netherlands Institute for Sea Research (NIOZ) in the framework of the ongoing multidisciplinary projects TRAFFIC, funded by the Netherlands Organization for Scientific Research (NWO; project no. 822.01.008), and DUSTTRAFFIC, funded by the European Research Council (ERC; project no. 311152). Lab preparation of the $1 / 5$ split of the original sediment trap sample was conducted at the NIOZ, whereas the splitting, filtering, and SEM taxonomical analysis were performed at the Geosciences Department of the University of Bremen, Germany. The first author benefited from a Marie Curie postdoctoral fellowship supported by the University of Bremen and the European Union FP7 COFUND under grant agreement no. 600411. Regarding the satellite data used in this study, the authors would like to acknowledge the following: the MODIS Atmosphere Science Team, the Aerosol Retrieval Group, and the MODIS Adaptive Processing System (MODAPS); the NASA EOSDIS Physical Oceanography Distributed Active Archive Centre (PO.DAAC) (http://podaac.jpl.nasa.gov/SeaSurfaceSalinity/Aquarius); and the Ocean Biology Processing Group (OBPG) and the Atmosphere Archive and Distribution System (LAADS) at the NASA Goddard Space Flight Center. The CCMP version 2.0 vector wind analyses were produced by Remote Sensing Systems (www.remss.com) and the CMAP precipitation data were provided by NOAA/OAR/ESRL PSD, Boulder, Colorado, USA (http://www.esrl.noaa.gov/psd/) The authors are thankful to Leandro Ponsoni, Lluisa Cros, Oliver Knebel, and Friederike Ebersbach for their contributions during the discussion of the data and to Alex Poulton and two anonymous referees for their constructive reviews.

The article processing charges for this open-access publication were covered by the University of Bremen.

Edited by: Emilio Marañón

Reviewed by: Alex Poulton and two anonymous referees

\section{References}

Andruleit, H.: A filtration technique for quantitative studies of coccoliths, Micropaleontology, 42, 403-406, 1996.

Armstrong, R. A., Lee, C., Hedges, J. I., Honjo, S., and Wakeham, S. G.: A new, mechanistic model of organic carbon fluxes in the ocean based on the quantitative association of POC with ballast minerals, Deep-Sea Res. Pt. II, 49, 219-236, 2002. 
Atlas, R., Hoffman, R. N., Ardizzone, J., Leidner, S. M., Jusem, J. C., Smith, D. K., and Gombos, D.: A cross-calibrated, multiplatform ocean surface wind velocity product for meteorological and oceanographic applications, B. Am. Meteorol. Soc., 92, 157-174, 2011.

Baker, A. R., Jickells, T. D., Biswas, K. F., Weston, K., and French, M.: Nutrients in atmospheric aerosol particles along the Atlantic Meridional Transect, Deep-Sea Res. Pt. II, 53, 17061719, 2006.

Basha, G., Kishore, P., Venkat Ratnamc, M., Ouarda, T. B. M. J., Velicogna, I., and Sutterley, T.: Vertical and latitudinal variation of the intertropical convergence zone derived using GPS radio occultation measurements, Remote Sens. Environ., 163, 262269,2015

Baumann, K.-H., Andruleit, H., Bockel, B., Geisen, M., and Kinkel, H.: The significance of extant coccolithophores as indicators of ocean water masses, surface water temperature, and paleoproductivity: a review, Palaeont. Z., 79, 93-112, 2005.

Beaufort, L. and Heussner, S.: Coccolithophorids on the continental slope of the Bay of Biscay - production, transport and contribution to mass fluxes, Deep-Sea Res. Pt. II, 46, 2147-2174, 1999.

Beaufort, L. and Heussner, S.: Seasonal dynamics of calcareous nannoplankton on a West European continental margin: the Bay of Biscay, Mar. Micropaleontol., 43, 27-55, 2001.

Beaufort, L., Lancelot, Y., Camberlin, P., Cayre, O., Vincent, E., Bassinot, F., and Labeyrie, L.: Insolation Cycles as a Major Control of Equatorial Indian Ocean Primary Production, Science, 278, 1451-1454, 1997.

Boeckel, B. and Baumann, K.-H.: Vertical and lateral variations in coccolithophore community structure across the subtropical frontal zone in the South Atlantic Ocean, Mar. Micropaleontol., 76, 255-273, 2008.

Boeckel, B., Baumann, K.-H., Henrich, R., and Kinkel, H.: Coccolith distribution patterns in South Atlantic and Southern Ocean surface sediments in relation to environmental gradients, DeepSea Res. Pt. I, 53, 1073-1099, 2006.

Boyle, E. A., Edmond, J. M., and Sholkovitz, E. R.: On the mechanism of iron removal in estuaries, Geoch. Geoph. Acta, 41, 13131324, 1977.

Bristow, C. S., Hudson-Edwards, K. A., and Chappell, A.: Fertilizing the Amazon and equatorial Atlantic with West African dust, Geophys. Res. Lett., 37, L14807, https://doi.org/10.1029/2010GL043486, 2010.

Broerse, A. T. C., Ziveri, P., van Hinte, J. E., and Honjo, S.: Coccolithophore export production, species composition and coccolith$\mathrm{CaCO}_{3}$ fluxes in the NE Atlantic $\left(34^{\circ} \mathrm{N} 21^{\circ} \mathrm{W}\right.$ and, $48^{\circ} \mathrm{N}$ $21^{\circ}$ W). Deep-Sea Res. Pt. II, 47, 1877-1906, 2000.

Carpenter, E. J., Montoya, J. P., Burns, J., Mulholland, M. R., Subramaniam, A., and Capone, D. G.: Extensive bloom of a $\mathrm{N}_{2}$-fixing diatom/cyanobacterial association in the tropical Atlantic Ocean, Mar. Ecol.-Prog. Ser., 185, 273-283, 1999.

Cros, L. and Fortuño, J.-M.: Atlas of northwestern Mediterranean coccolithophores, Sci. Mar., 66, 7-182, 2002.

De Master, D. J., Kuehl, S. A., and Nittrouer, C. A.: Effects of suspended sediments on geochemical processes near the mouth of the Amazon River: examination of biogenic silica uptake and the fate of particle-reactive elements, Cont. Shelf Res., 6, 107-125, 1986.
Deuser, W. G., Ross, E. H., and Anderson, R. F.: Seasonality in the supply of sediment to the deep Sargasso Sea and implications for the rapid transfer of matter to the deep ocean, Deep-Sea Res. I, 28A, 495-505, 1981.

Dufois, F., Hardman-Mountford, N. J., Greenwood, J., Richardson, A. J., Feng, M., and Matear, R. J.: Anticyclonic eddies are more productive than cyclonic eddies in subtropical gyres because of winter mixing, Sci. Adv., 2, 1600282, https://doi.org/10.1126/sciadv.1600282, 2016.

Emery, W. J. and Meincke, J.: Global water masses: summary and review, Oceanol. Acta, 9, 383-391, 1986.

Falkowski, P. G., Barber, R. T., and Smetacek, V.: Biogeochemical Controls and Feedbacks on Ocean Primary Production, Science, 281, 200-207, 1998.

Fallet, U., van Assen, C., Boer, W., Greaves, M., and Brummer, G.-J. A.: A novel application of wet-oxidation to retrieve carbonates from large organic-rich samples for ocean-Clim. Res., Geochem. Geophy. Geosy., 10, Q08004, https://doi.org/10.1029/2009GC002573, 2009.

Ffield, A.: North Brazil current rings viewed by TRMM Microwave Imager SST and the influence of the Amazon Plume, Deep-Sea Res. Pt. I, 52, 137-160, 2005.

Fischer, G. and Karakaş, G.: Sinking rates and ballast composition of particles in the Atlantic Ocean: implications for the organic carbon fluxes to the deep ocean, Biogeosciences, 6, 85102, https://doi.org/10.5194/bg-6-85-2009, 2009.

Fischer, G., Romero, O., Merkel, U., Donner, B., Iversen, M., Nowald, N., Ratmeyer, V., Ruhland, G., Klann, M., and Wefer, G.: Deep ocean mass fluxes in the coastal upwelling off Mauritania from 1988 to 2012: variability on seasonal to decadal timescales, Biogeosciences, 13, 3071-3090, https://doi.org/10.5194/bg-13-3071-2016, 2016.

Garzoli. S. and Katz, E. J.: The forced reversal of the Atlantic North equatorial countercurrent, J. Phys. Oceanogr., 13, 2082-2090, 1983.

Giraudeau, J. and Bayley, G. W.: Spatial dynamics of coccolithophore communities during an upwelling event in the Southern Benguela system, Cont. Shelf Res., 15, 1825-1852, 1995.

Goes, J. I., Gomes, H. R., Chekalyuk, A. M., Carpenter, E. J., Montoya, J. P., Coles, V. J., Yager, P. L., Berelson, W. M., Capone, D. G., Foster, R. A., Steinberg, D. K., Subramaniam, A., and Hafez, M. A.: Influence of the Amazon River discharge on the biogeography of phytoplankton communities in the western tropical north Atlantic, Prog. Oceanogr., 120, 29-40, 2014.

Goni, G. J. and Johns, W. E.: A census of North Brazil current rings observed from TOPEX/POSEIDON altimetry: 1992-1998, Geophys. Res. Lett., 28, 1-4, 2001.

Goudie, A. S. and Middleton, N. J.: Saharan dust storms: nature and consequences, Earth-Sci. Rev., 56, 179-204, 2001.

Guerreiro, C., Oliveira, A., Cachão, M., de Stigter, H., Sá, C., Borges, C., Cros, C., Santos, A., and Rodrigues, A.: Late winter coccolithophore bloom off central Portugal in response to river discharge and upwelling, Cont. Shelf Res., 59, 65-83, 2013.

Guieu, C., Aumont, O., Paytan, A., Bopp, L., Law, C. S., Mahowald, N., Achterberg, E. P., Marañón, E., Salihoglu, B., Crise, A., Wagener, T., Herut, B., Desboeufs, K., Kanakidou, M., Olgun, N., Peters, F., Pulido-Villena, E., Tovar-Sanchez, A., and Völker, C.: The significance of the episodic nature of atmospheric deposition to Low Nutrient Low Chlorophyll regions, Global Biogeochem. 
Cy., 28, 1179-1198, https://doi.org/10.1002/2014GB004852, 2014

Haidar, A. T. and Thierstein, H. R.: Coccolithophore dynamics off Bermuda (N. Atlantic), Deep-Sea Res. Pt. II, 48, 1925-1956, 2001

Hastenrath, S. and Merle, J.: Annual Cycle of Subsurface Thermal Structure in the Tropical Atlantic Ocean, J. Phys. Oceanogr., 17, 1518-1538, 1987.

Honjo, S.: Seasonality and interaction of biogenic and lithogenic particle flux at the Panama Basin, Science, 281, 883-884, 1982.

Jickells, T. D., An, Z. S., Andersen, K. K., Baker, A. R., Bergametti, G., Brooks, N., Cao, J. J., Boyd, P. W., Duce, R. A., Hunter, K. A., Kawahata, H., Kubilay, N., laRoche, J., Liss, P. S., Mahowald, N., Prospero, J. M., Ridgwell, A. J., Tegen, I., and Torres, R.: Global Iron Connections Between Desert Dust, Ocean Biogeochemistry, and Climate, Science, 308, 67-71, 2005.

Johns, W., Lee, T., Beardsley, R. C., Candela, J., Limeburner, R., and Castro, B.: Annual cycle and variability of the North Brazil Current, J. Phys. Oceanogr., 28, 103-128, 1998.

Jordan, R., Cros, L., and Young, J. A revised classification scheme for living haptophytes, Micropaleontol., 50, 55-79, 2004.

Kinkel, H., Baumann, K.-H., and Cepek, M.: Coccolithophores in the equatorial Atlantic Ocean: response to seasonal and Late Quaternary surface water variability, Mar. Micropaleontol., 39, 87-112, 2000.

Knappertsbusch, M. and Brummer, G.-J. A.: A sediment trap investigation of sinking coccolithophores in the North Atlantic, DeepSea Res. I, 42, 1083-1109, 1995.

Knebel, O.: Production and export fluxes of biomineralising microplankton in the equatorial mid North Atlantic Ocean, MSc Thesis (AM_1147, 24 ects), Vrije Universiteit Amsterdam, Amsterdam, the Netherlands, 190 pp., 2016.

Köbrich, M. I. and Baumann, K.-H.: Coccolithophore flux in a sediment trap off Cape Blanc (NW Africa), J. Nannoplankton Res., 30, 83-96, 2009.

Köbrich, M. I., Baumann, K.-H., and Fischer, G.: Seasonal and inter-annual dynamics of coccolithophore fluxes from the upwelling region off Cape Blanc, NW Africa, J. Micropalaeontol., 35, 103-116, https://doi.org/10.1144/jmpaleo2014-024, 2015.

Korte, L. F., Brummer, G.-J. A., van der Does, M., Guerreiro, C. V., Hennekam, R., van Hateren, J. A., Jong, D., Munday, C. I., Schouten, S., and Stuut, J.-B. W.: Downward particle fluxes of biogenic matter and Saharan dust across the equatorial North Atlantic, Atmos. Chem. Phys., 17, 6023-6040, https://doi.org/10.5194/acp-17-6023-2017, 2017.

Lelli, L., von Hoyningen-Huene, W., Vountas, M., Jäger, M., and Burrows, J. P.: Dust deposition rates derived from optical satellite observations, Past. Glob. C., 22, 64-65, 2014.

Lenes, J. M., Prospero, J. M., Landing, W. M., Virmani, J. I., and Walsh, J. J.: A model of Saharan dust deposition to the eastern Gulf of Mexico, Mar. Chem., 134, 1-9, 2012.

Levy, R., Hsu, C., et al.: MODIS Atmosphere L2 Aerosol Product, NASA MODIS Adaptive Processing System, Goddard Space Flight Center, USA, 2015.

Longhurst, A.: Seasonal cooling and blooming in tropical oceans, Deep-Sea Res. I, 40, 2145-2165, 1993.

Longhurst, A., Sathyendranath, S., Platt, T., and Caverhill, C.: An estimate of global primary production in the ocean from satellite radiometer data, J. Plankton Res., 17, 1245-1271, 1995.
Lux, M., Mercier, H., and Arhan, M.: Interhemispheric exchanges of mass and heat in the Atlantic Ocean in January-March 1993, Deep-Sea Res. I, 48, 605-638, 2001.

Mahowald, N., Jickells, T. D., Baker, A. R., Artaxo, P., BenitezNelson, C. R., Bergametti, G., Bond, T. C., Chen, Y., Cohen, D. D., Herut, B., Kubilay, N., Losno, R., Luo, C., Maenhaut, W., McGee, K. A., Okin, G. S., Siefert, R. L., and Tsukuda, S.: Global distribution of atmospheric phosphorous sources, concentration and deposition rates, and anthropogenic impacts, Global Biogeochem. Cy., 22, GB4026, https://doi.org/10.1029/2008GB003240, 2008.

Mahowald, N. M., Engelstaedter, S., Luo, C., Sealy, A., Artaxo, P., Benitez-Nelson, C., Bonnet, S., Chen, Y., Chuang, P. Y., Cohen, D. D., Dulac, F., Herut, B., Johansen, A. M., Kubilay, N., Losno, R., Maenhaut, W., Paytan, A., Prospero, J. M., Shank, L. M., and Siefert, R. L.: Atmospheric iron deposition: global distribution, variability, and human perturbations, Annu. Rev. Mar. Sci., 1, 245-278, 2009.

Mann, K. H. and Lazier, J. R.: Dynamics of Marine Ecosystems, Biological-Physical Interactions in the Oceans, 3 Edn., Blackwell Publishing, Malden, MA, Oxford, UK, 512 pp., 2006.

Margalef, R.: Life-forms of phytoplankton as survival alternatives in an unstable environment, Oceanol. Acta, 1, 493-509, 1978.

Martin, J. H.: Glacial-Interglacial $\mathrm{CO}_{2}$ change: the Iron Hypothesis, Paleoceanography, 5, 1-13, 1990.

Martino, M., Hamilton, D., Baker, A. R., Jickells, T. D., Bromley, T., Nojiri, Y., Quack, B., and Boyd, P. W.: Western Pacific atmospheric nutrient deposition fluxes, their impact on surface ocean productivity, Global Biogeochem. Cy., 28, 712-728, https://doi.org/10.1002/2013GB004794, 2014.

Milliman, J. D.: Production and accumulation of calcium carbonate in the ocean: budget of a nonsteady state, Global Biogeochem. Cy., 7, 927-957, 1993.

Mills, M. M., Ridame, C., Davey, M., Roche, J. L., and Geider, R. J.: Iron and phosphorus co-limit nitrogen fixation in the eastern tropical North Atlantic, Nature, 429, 292-294, 2004.

Molfino, B. and McIntyre, A.: Precessional forcing of nutricline dynamics in the equatorial Atlantic, Science, 249, 766-769, 1990.

Molleri, G. S. F., Novo, E. M. L., and Kampel, M.: Space-time variability of the Amazon River plume based on satellite ocean color, Cont. Shelf Res., 30, 342-352, 2010.

Muller-Karger, F., McClain, C., and Richardson, P.: The dispersal of the Amazon's water, Nature, 333, 56-58, 1988.

Nanninga, J. H. and Tyrrell, T.: Importance of light for the formation of algal blooms by Emiliania huxleyi, Mar. Ecol.-Prog. Ser., 136, 195-203, 1996.

Neuer, S., Torres-Padron, M. E., Gelado-Caballero, M. D., Rueda, M. J., Hernandez-Brito, J., Davenport, R., and Wefer, G.: Dust deposition pulses to the eastern subtropical North Atlantic gyre: Does ocean's biogeochemistry respond?, Global Biogeochem. Cy., 18, GB4020, https://doi.org/10.1029/2004GB002228, 2004.

Okada, H. and Honjo, S.: The distribution of oceanic coccolithophorids in the Pacific, Deep-Sea Res., 20, 355-374, 1973.

Okin, G. S., Baker, A. R., Tegen, I., Mahowald, N. M., Dentener, F. J., Duce, R. A., Galloway, J. N., Hunter, K., Kanakidou, M., Kubilay, N., Prospero, J. M., Sarin, M., Surapipith, V., Uematsu, M., and Zhu, T.: Impacts of atmospheric nutrient deposition on marine productivity: roles of nitrogen, 
phosphorous and iron, Global Biogeochem. Cy., 25, GB2022, https://doi.org/10.1029/2010GB003858, 2011.

Oschlies, A. and Garçon, V.: Eddy-induced enhancement of primary production in a coupled ecosystem-circulation model of the North Atlantic Ocean, Nature, 394, 266-269, 1998.

Pabortsava, K., Lampitt, R. S., Benson, J., Crowe, C., McLachlan, R., Le Moigne, F. A. C., Moore, C. M., Pebody, C., Provost, P., Rees, A. P., Tilstone, G. H., and Woodward, E. M. S.: Carbon sequestration in the deep Atlantic enhanced by Saharan dust, Nat. Geosci., 10, 189-194, https://doi.org/10.1038/ngeo2899, 2017.

Philander, S. G.: Atlantic Ocean Equatorial Currents, Encyclopedia of Ocean Sciences 2001, 188-191, https://doi.org/10.1006/rwos.2001.0361, 2001.

Poulton, A. J., Holligan, P. M., Charalampopoulou, A., and Adey, T. R.: Coccolithophore ecology in the tropical and subtropical Atlantic Ocean: new perspectives from the Atlantic Meridional Transect (AMT) programme, Prog. Oceanogr., https://doi.org/10.1016/j.pocean.2017.01.003, 2017.

Prospero, J., Collard, F-X., Molinié, J., and Jeannot, A.: Characterizing the annual cycle of African dust transport to the Caribbean Basin and South America and its impact on the environment and air quality, Global Biogeochem. Cy., 29, 757-773, 2014.

Reid, J. L.: On the total geostrophic circulation of the North Atlantic Ocean: flow patterns, tracers, and transports, Prog. Oceanogr., 33, 1-92, 1994.

Richardson, P. L. and Walsh, D.: Mapping Climatological SeasonalVariations of Surface Currents in the Tropical Atlantic Using Ship Drifts, J. Geophys. Res., 91, 10537-10550, 1986.

Ridame, C., Dekaezemacker, J., Guieu, C., Bonnet, S., L'Helguen, S., and Malien, F.: Contrasted Saharan dust events in LNLC environments: impact on nutrient dynamics and primary production, Biogeosciences, 11, 4783-4800, https://doi.org/10.5194/bg-114783-2014, 2014.

Romero, O., Boeckel, B., Donner, B., Lavik, G., Fischer, G., and Wefer, G.: Seasonal productivity dynamics in the pelagic central Benguela System inferred from the flux of carbonate and silicate organisms, J. Marine Syst., 37, 259-278, 2002.

Romero, E., Peters, F., Marraseì, C., Guadayol, O., Gasola, J. M., and Weinbauer, M. G.: Coastal Mediterranean plankton stimulation dynamics through a dust storm event: an experimental simulation, Estuar. Coast. Shelf S., 93, 27-39, 2011.

Rost, B. and Riebesell, U.: Coccolithophores and the biological pump: responses to environmental changes. in: Coccolithophores: from Molecular Processes to Global Impact, edited by: Thierstein, H. R. and Young, J. R., Springer, Berlin, 99-125, 2004.

Roth, P. H. and Berger, H.: Distribution and dissolution of coccoliths in the South and Central Pacific, in: Dissolution of DeepSea Carbonates, 13, edited by: Sliter, W. V., Be, A. W. H. and Berger, W. H., Cushman Found, Foraminiferal Res. Spec. Pub., American Science Foundation, 87-113, 1975.

Schott, F. A., Fischer, J. and Stramma, L.: Transports and pathways of the upper- layer circulation in the western tropical Atlantic, J. Phys. Oceanogr., 28, 1904-1928, 1998.

Sholkovitz, E. R., Boyle, E. A., and Price, N. B.: The removal of dissolved humic acids and iron during estuarine mixing, Earth Planet. Sc. Lett., 40, 130-136, 1978.

Signorini, S. R. and McClain, C. R.: Subtropical gyre variability as seen from satellites, Remote Sens. Lett., 3, 471-479, 2012.
Sprengel, C., Baumann, K.-H., Henderiks, J., Henrich, R., and Neuer, S.: Modern coccolithophore and carbonate sedimentation along a productivity gradient in the Canary Islands region: seasonal export production and surface accumulation rates, DeepSea Res. II, 49, 3577- 3598, 2002.

Steinmetz, J. C.: Sedimentation of coccolithophores, in: Coccolithophores, edited by: Winter, A., and Siesser, W., Cambridge University Press, Cambridge, 13-37, 1994.

Stoll, H. M., Arevalos, A., Burke, A., Ziveri, P., Mortyn, G., Shimizu, N., and Unger, D.: Seasonal cycles in biogenic production and export in Northern Bay of Bengal sediment traps, Deep-Sea Res. II, 54, 558-580, 2007.

Stramma, L. and England, M.: On the water masses and mean circulation of the South Atlantic Ocean, J. Geophys. Res., 104, 20863-20883, 1999.

Stramma, L. and Schott, F.: The mean flow field of the tropical Atlantic Ocean, Deep-Sea Res. II, 46, 279-303, 1999.

Stramma, L., Fischer, J., Brandt, P., and Schott, F.: Circulation, variability and near-equatorial meridional flow in the central tropical Atlantic, in: Interhemispheric Water Exchange in the Atlantic Ocean, edited by: Goni, G. J. and Malanotte-Rizzoli, P., 22 pp., 2003.

Stuut, J.-B. and Prins, M.: The significance of particle size of longrange transported mineral dust, Past Glob. Changes, 22, 70-71, 2014.

Stuut, J.-B. W., Brummer, G.-J., van der Does, M., Friese, C., Geerken, E., van der Heide, R., Korte, L., Koster, B., Metcalfe, B., Munday, C., van Ooijen, J., Siccha, M., Veldhuizen, R., de Visser, J.-D., Witte, Y., and Wuis, L.: Cruise report and preliminary results (64PE378), TRAFFIC II: Transatlantic fluxes of Saharan dust (Las Palmas de Gran Canaria, Spain - St. Maarten), Royal NIOZ, the Netherlands, 54 pp., 2013.

Stuut, J.-B. W., Witte, Y., de Visser, J.-D., Boersen, B., Koster, B., Bakker, K., Laan, P., van der Does, M., Korte, L., Munday, C., and van Hateren, H.: Cruise report and preliminary results (64PE378), DUSTTRAFFIC III: Transatlantic fluxes of Saharan dust (Mindelo, Sao Vicente (Cape-Verdian Islands) Bridgetown, Barbados), Royal NIOZ, the Netherlands, 51 pp., 2015.

Stuut, J.-B. W., Boekschoten, B., Boersen, B., Brummer, G.-J., Brussaard, C., de Boer, J., de Bruin, T., Jong, D., Knebel, O., Kooijman, K., Korte, L., Koster, B., Laan, P., Martens, M., Munday, C., Noordeloos, A., Pausch, F., Roepert, A., Rosell-Melé, T., Schreuder, L., Sevenster, L., van der Does, M., Venhuizen, G., Guerreiro, C. V., and Witte, Y.: Cruise report and preliminary results (JC134). DUSTTRAFFIC IV: Transatlantic fluxes of Saharan dust (St. Johns, Antigua - Sta. Cruz, Tenerife, Spain), Royal NIOZ, the Netherlands, 101 pp., 2016.

Talley, L. D.: Antarctic intermediate water in the South Atlantic, in: The South Atlantic - Present and Past Circulation, edited by: Wefer, G., Berger, W. H., Siedler, G. and Webb, D. J., Springer, Berlin, 219-238, 1996

Tuomisto, H.: Defining, Measuring, and Partitioning Species Diversity, Encyclopedia of Biodiversity, 2, 434-446, https://doi.org/10.1016/B978-0-12-384719-5.00378-6, 2013.

Tyrell, T. and Merico, A.: Emiliania huxleyi: bloom observations and the conditions that induce them, in: Coccolithophores From Molecular Processes to Global Impact, edited by: Thierstein, H. R. and Young, J. R., Springer, Berlin, 75-98, 2004. 
van der Does, M., Korte, L. F., Munday, C. I., Brummer, G.-J. A., and Stuut, J.-B. W.: Particle size traces modern Saharan dust transport and deposition across the equatorial North Atlantic, Atmos. Chem. Phys., 16, 13697-13710, https://doi.org/10.5194/acp-16-13697-2016, 2016.

van der Jagt, H., Friese, C., Stuut, J.-B., W., Fischer, G., and Iversen, M. H.: The ballasting effect of Saharan dust deposition on aggregate dynamics and carbon export: aggregation, settling and scavenging of marine snow, Limnol. Oceanogr., submitted, 2017.

Walsh, J. J., Jolliff, J. K., Darrow, B. P., Lenes, J. M., Milroy, S. P., Remsen, A., Dieterle, D. A., Carder, K. L., Chen, F. R., Vargo, G. A., Weisberg, R. H., Fanning, K. A., Muller-Karger, F. E., Shinn, E., Steidinger, K. A., Heil, C. A., Tomas, C. R., Prospero, J. S., Lee, T. N., Kirkpatrick, G. J., Whitledge, T. E., Stockwell, D. A., Villareal, T. A., Jochens, A. E., and Bontempi, P. S.: Red tides in the Gulf of Mexico: where, when, and why?, J. Geophys. Res., 111, C11003, https://doi.org/10.1029/2004JC002813, 2006.

Wang, X., Murtugudde, R., Hackert, E., and Marañón, E.: Phytoplankton carbon and chlorophyll distributions in the equatorial Pacific and Atlantic: a basin-scale comparative study, J. Marine Syst., 109-110, 138-148, 2013.

Waniek, J., Koeve1, W., and Prien, R. D.: Trajectories of sinking particles and the catchment areas above sediment traps in the northeast Atlantic, J. Mar. Res., 58, 983-1006, 2000.

Wilson, W. D., Johns, E., and Molinari, R. L.: Upper layer circulation in the western tropical North Atlantic Ocean during August 1989, J. Geophys. Res., 99, 22513-22523, 1994.

Winter, A., Jordan, R., and Roth, P.: Biogeography of living coccolithophores in ocean waters. in: Coccolithophores, edited by: Winter, A. and Siesser, W., Cambridge Univ. Press, 161-177, 1994.
Winter, A., Rost, B., Hilbrecht, H., and Elbrachter, M.: Vertical and horizontal distribution of coccolithophores in the Caribbean Sea, Geo-Mar. Lett., 22, 150-161, 2002.

Xie, P. and Arkin, P. A.: Global precipitation: a 17 year monthly analysis based on gauge observations, satellite estimates, and numerical model outputs, B. Am. Meteorol. Soc., 78, 2539-2558, 1997.

Young, J.: Functions of coccoliths. in: Coccolithophores, edited by: Winter, A. and Siesser, W., Cambridge Univ. Press, Cambridge, 63-82, 1994.

Young, J. R., Bown, P. R., and Lees, J. A. (Eds.): Nannotax website, International Nannoplankton Association, http://www.mikrotax. org/Nannotax3/, last access: 21 September 2011.

Ziveri, P., Thunell, R. C., and Rio, D.: Export production of coccolithophores in an upwelling region: results from San Pedro Basin, Southern California Borderlands, Mar. Micropaleontol., 24, 335358, 1995.

Ziveri, P., Baumann, K.-H., Boeckel, B., Bollmann, J., and Young, J. R.: Biogeography of selected Holocene coccoliths in the Atlantic Ocean. in: Coccolithophores - From Molecular Processes to Global Impact, edited by: Thierstein, H. R. and Young, J. R., Springer, Berlin, 403-428, 2004.

Ziveri, P., de Bernard, B., Baumann, K.-H., Stoll, H. M., and Morty, P. G.: Sinking of coccolith carbonate and potential contribution to organic carbon ballasting in the deep ocean, Deep-Sea Res. Pt II, 54, 659-675, 2007. 